Nat. Hazards Earth Syst. Sci., 19, 337-352, 2019

https://doi.org/10.5194/nhess-19-337-2019

(C) Author(s) 2019. This work is distributed under the Creative Commons Attribution 4.0 License.

\title{
Reanalysis of the 1761 transatlantic tsunami
}

\author{
Martin Wronna ${ }^{1,3, *}$, Maria Ana Baptista ${ }^{1,2}$, and Jorge Miguel Miranda ${ }^{1,3}$ \\ ${ }^{1}$ Instituto Dom Luiz, Faculdade de Ciências da Universidade de Lisboa, Lisbon, Portugal \\ ${ }^{2}$ Instituto Superior de Engenharia de Lisboa, Instituto Politécnico de Lisboa, Lisbon, Portugal \\ ${ }^{3}$ Instituto Português do Mar e da Atmosfera, IP, Lisbon, Portugal \\ * Invited contribution by Martin Wronna, recipient of the EGU Natural Hazards Outstanding Student Poster \\ and PICO Award 2016.
}

Correspondence: Martin Wronna (mawronna@fc.ul.pt)

Received: 4 February 2018 - Discussion started: 19 March 2018

Revised: 18 January 2019 - Accepted: 21 January 2019 - Published: 13 February 2019

\begin{abstract}
The segment of the Africa-Eurasia plate boundary between the Gloria Fault and the Strait of Gibraltar has been the setting of significant tsunamigenic earthquakes. However, their precise location and rupture mechanism remain poorly understood. The investigation of each event contributes to a better understanding of the structure of this diffuse plate boundary and ultimately leads to a better evaluation of the seismic and tsunami hazard. The 31 March 1761 event is one of the few known transatlantic tsunamis. Macroseismic data and tsunami travel times were used in previous studies to assess its source area. However, no one discussed the geological source of this event. In this study, we present a reappraisal of tsunami data to show that the observations data set is compatible with a geological source close to Coral Patch and Ampere seamounts. We constrain the rupture mechanism with plate kinematics and the tectonic setting of the area. This study favours the hypothesis that the 1761 event occurred in the southwest of the likely location of the 1 November 1755 earthquake in a slow deforming compressive regime driven by the dextral transpressive collision between Africa and Eurasia.
\end{abstract}

\section{Introduction}

The coast along the southwest Iberian margin is prone to earthquakes and tsunamis. The earthquake and tsunami catalogues for the Iberian Peninsula and Morocco report three tsunamigenic earthquakes in the 18th century: 1722, 1755 and 1761 (Mezcua and Solares, 1983; Oliveira, 1986; Baptista and Miranda, 2009). While the 1722 event is believed to be a local event (Baptista et al., 2007), the 1 November 1755 and the 31 March 1761 earthquakes generated transatlantic tsunamis (Baptista et al., 1998a, b, 2003, 2006; Barkan et al., 2009). The source of the 1755 event has been extensively studied in recent years, e.g. by Baptista et al. (1998a, b), Zitellini et al. (2001), Gutscher et al. (2006) and Barkan et al. (2009).

On the contrary, the tectonic source of 31 March 1761 remains poorly understood. The seismic catalogues present different earthquake locations: $10.00^{\circ} \mathrm{W}, 37.00^{\circ} \mathrm{N}$ (Mezcua and Solares, 1983) or $10.50^{\circ} \mathrm{W}, 36.00^{\circ} \mathrm{N}$ (Oliveira, 1986). Baptista et al. (2006), used macroseismic intensity data and tsunami travel time observations to locate the source circa $13.00^{\circ} \mathrm{W}, 34.50^{\circ} \mathrm{N}$ and estimated the magnitude in 8.5. The source location obtained by Baptista et al. (2006) places the 1761 event southwest of the Southwest Iberian Margin (SWIM) in the outer part of the Gulf of Cadiz (Fig. 1). The plate boundary between Eurasia and Africa is not well defined in the SWIM area, as the deformation is distributed over a large area. Here, a complex system of faults accommodates the stress driven by the present-day tectonic regime that is constrained by NW-SE plate convergence between Africa and Eurasia at $\sim 4 \mathrm{~mm}^{-1}$ year $^{-1}$ (Argus et al., 1989; DeMets et al., 1994) and by the westward migration of the Cadiz Subduction slab $\sim 2$ mm year $^{-1}$ (Gutscher et al., 2012; Duarte et al., 2013).

The SWIM is dominated by large NE-SW-trending structures limiting the Horseshoe Abyssal Plain (HAP) (Fig. 1). The NE-SW-striking structures are the Coral Patch Fault (CPF) (Martínez-Loriente et al., 2013), the Gorringe Bank Fault (GBF) (Zitellini et al., 2009; Jiménez-Munt et al., 2010; 
Sallarès et al., 2013; Martínez-Loriente et al., 2014), the Horseshoe Fault (HSF) (Gràcia et al., 2003; Zitellini et al., 2004; Martínez-Loriente et al., 2018) and the Marques de Pombal Fault (MPF) (Gràcia et al., 2003; Terrinha et al., 2003; Zitellini et al., 2004) (Fig. 1). Other identified NE-SWtrending structures are the São Vicente Fault (SVF) (Gràcia et al., 2003; Zitellini et al., 2004), the Horseshoe Abyssal Plain Thrust (HAT) (Martínez-Loriente et al., 2014) and to the south of the CPF, the Seine Hills (SH) (Martínez-Loriente et al., 2013) (Fig. 1).

Large WNW-ESE-trending dextral strike-slip faults (the northern WNW-ESE-trending lineament, LN, and the southern WNW-ESE-trending lineament, LS) further characterise the SWIM cutting through the Gulf of Cadiz to the HAP (Zitellini et al., 2009; Terrinha et al., 2009; Rosas et al., 2009) (Fig. 1). To the south, the igneous Ampere and Coral Patch seamounts limit the HAP.

In this study, we investigate the geological source of the 1761 transatlantic tsunami. To do this, we start with a reappraisal of previous research, we analyse the tectonic setting of the area and propose a source compatible with plate kinematics. From this source, we compute the initial sea surface displacement. To propagate the tsunami, we build a bathymetric data set based on GEBCO (2014) data to compute wave heights offshore of the observations points presented in Table 1. We also compute inundation using highresolution digital elevations models comprising topography and bathymetry in Lisbon and Cadiz to compare the results with the observations. Finally, we use Cadiz and Lisbon observations in 1755 and 1761 to compare the sizes of the events.

\section{Geodynamic context}

The plate boundary between Africa and Eurasia in the NE Atlantic Ocean, the Azores - Gibraltar fracture zone (AGFZ), extends from the Azores Triple Junction (ATJ) to the Gibraltar Arc. The main features of the AGFZ are the ATJ; the Gloria Fault (GF) and the SWIM (Fig. 1). At the ATJ, active interplate deformation defines the plate boundary (Fernandes et al., 2006). The GF is a large W-E-striking strike-slip fault with scarce seismicity (Laughton and Whitmarsh, 1974) with a strong $M_{\mathrm{W}}=8.3$ event on 25 November 1941 (Gutenberg and Richter, 1949; Moreira, 1984; Baptista et al., 2016). The Gloria Fault defines a sharp boundary between Eurasia and Africa (Laughton and Whitmarsh, 1974). Further east, towards the Gulf of Cadiz, in the plate boundary is not clearly defined (Torelli et al., 1997; Zitellini et al., 2009). Largescale dynamics are imposed by convergence between Africa and Eurasia and by the westward propagation of the Gibraltar Arc. Most recent studies agree that the source of the 1755 Lisbon earthquake with a magnitude of about $8.5 \pm 0.3$ is in the SWIM (Johnston, 1996; Baptista et al., 1998b; Zitellini et

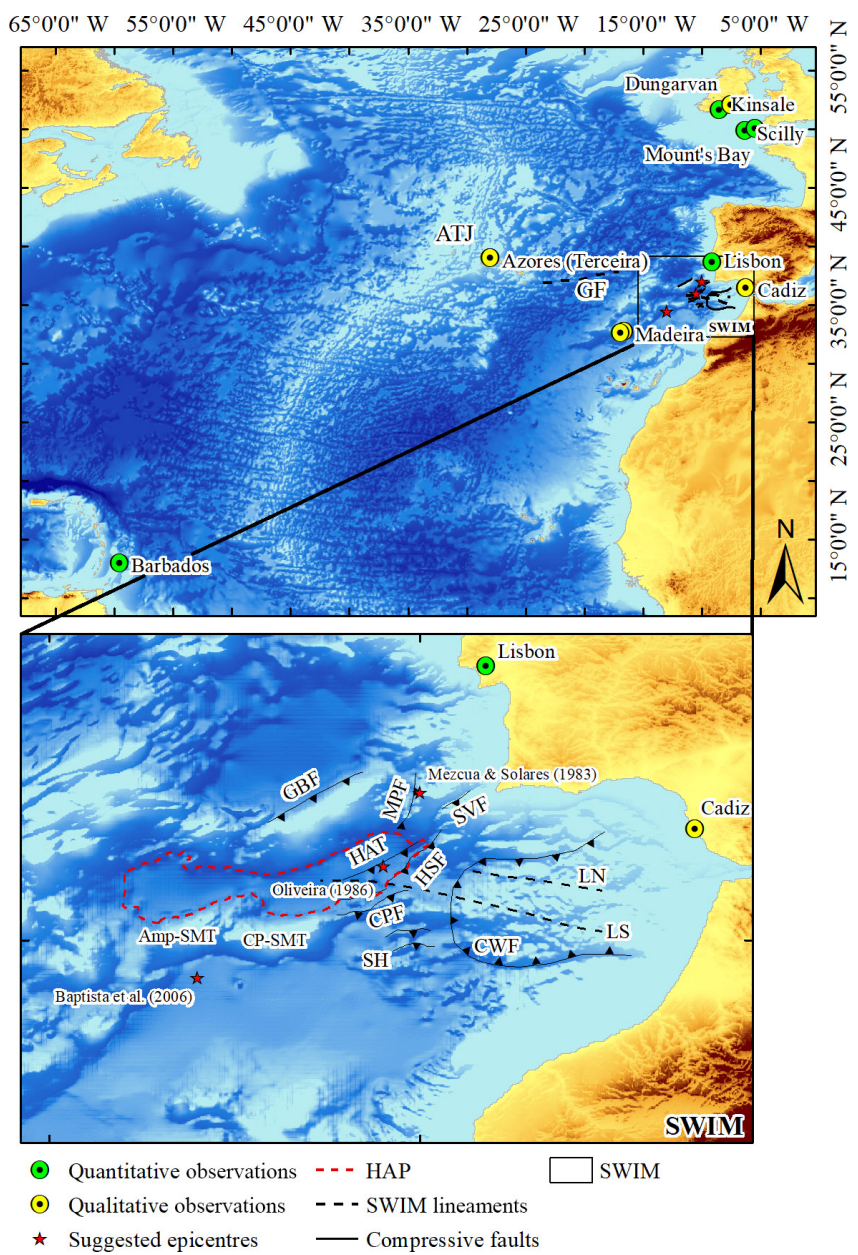

Figure 1. The red stars plot the source location by Oliveira (1986), Mezcua and Solares (1983) and Baptista et al. (2006). The green circles depict the quantitative tsunami observation points, and the yellow circles show the locations of the qualitative descriptions of the tsunami in 1761. The main features of the Azores Gibraltar fracture zone are the Azores Triple Junction (ATJ), the Gloria Fault (GF) and the Southwest Iberian Margin (SWIM). The inset shows the position of the Ampere seamount (Amp-SMT), the Coral Patch Seamount (CP-SMT) and the locations of the known faults. The black lines mark the faults, and the triangles indicate the direction of dip. The dashed black lines trace the main strike-slip faults. The known thrust faults are the Coral Patch Fault (CPF), the Cadiz Wedge Fault (CWF), the Gorringe Bank Fault (GBF), the Horseshoe Fault (HSF), the Marques de Pombal Fault (MPF), the Seine Hills (SH) and the São Vicente Fault (SVF). The shown strike-slip faults are the SWIM lineaments (LN) and (LS) and the Gloria Fault (GF). The dashed red line limits the Horseshoe Abyssal Plain (HAP).

al., 1999; Gutscher et al., 2002; Solares and Lopez-Arroyo, 2004; Ribeiro et al., 2006).

In the SWIM, two main sets of faults have been identified: large NE-SW-trending thrust faults and WNW-ESEtrending dextral strike-slip faults. 
Table 1. Summary of the available data of the 1761 tsunami at the time. The column TTT lists the observed tsunami travel times. The column polarity indicates the first movement of the sea upward (U) or downward (D).

\begin{tabular}{|c|c|c|c|c|c|c|c|c|c|}
\hline Location & Long. $\left({ }^{\circ}\right)$ & Lat. $\left({ }^{\circ}\right)$ & $\begin{array}{l}\text { Local } \\
\text { time }\end{array}$ & $\begin{array}{r}\text { TTT } \\
(\mathrm{h})\end{array}$ & $\begin{array}{r}\text { Wave height } \\
(\mathrm{m})\end{array}$ & Polarity & $\begin{array}{r}\text { Period } \\
(\min )\end{array}$ & Duration & Source \\
\hline Lisbon & -9.13 & 38.72 & $13: 15$ & 1.25 & $1.2-1.8$ & - & 6 & $\begin{array}{l}\text { Lasted until } \\
\text { night }\end{array}$ & $\begin{array}{l}\text { Unknown (1761); } \\
\text { Molloy (1761); } \\
\text { Borlase (1762) }\end{array}$ \\
\hline Cadiz & -6.29 & 36.52 & - & - & - & $\mathrm{D}$ & - & - & $\begin{array}{l}\text { Journal des } \\
\text { Matieres du } \\
\text { Temps (1773) }\end{array}$ \\
\hline Kinsale & -8.51 & 51.67 & 18:00 & 6 & 0.6 & $\mathrm{U}$ & 4 & $\begin{array}{l}\text { Repeated } \\
\text { several times }\end{array}$ & $\begin{array}{l}\text { Annual Regis- } \\
\text { ter (1761); } \\
\text { Borlase (1762) }\end{array}$ \\
\hline Isles of Scilly & -6.38 & 49.92 & $17: 00$ & 5 & $0.6-1.2$ & $\mathrm{U}$ & - & $>2 \mathrm{~h}$ & Borlase (1762) \\
\hline Mount’s Bay & -5.48 & 50.08 & $17: 00$ & 5 & $1.2-1.8$ & $\mathrm{U}$ & 12 & $1 \mathrm{~h}$ & Borlase (1762) \\
\hline Dungarvan & -7.48 & 51.95 & $16: 00$ & 4 & - & - & - & $5 \mathrm{~h}$ & Borlase (1762) \\
\hline Barbados & $\begin{array}{l}-59.57 \\
-59.57\end{array}$ & 13.03 & $16: 00$ & $7-8$ & $0.45-0.6$ & - & $3-6$ & $\begin{array}{l}4 \mathrm{~h} \text { but lasted } \\
\text { until } 6 \text { in the } \\
\text { morning. } \\
\text { Increased again } \\
\text { at } 10 \text { for short } \\
\text { time then de- } \\
\text { creased. }\end{array}$ & $\begin{array}{l}\text { Mason (1761); } \\
\text { Annual Regis- } \\
\text { ter (1761) } \\
\text { Borlase (1762) }\end{array}$ \\
\hline Madeira & -16.91 & 32.62 & - & - & $\sim 1$; higher in the east & - & - & $\begin{array}{l}\text { Lasted longer } \\
\text { in the east than } \\
\text { in the south. }\end{array}$ & Heberden (1761) \\
\hline Azores & -27.22 & 38.65 & - & - & Large & $\mathrm{U}$ & Some min. & $3 \mathrm{~h}$ & Fearns (1761) \\
\hline
\end{tabular}

Thrust faults include large NE-SW-trending structures, namely the Horseshoe Fault (HSF) (Gràcia et al., 2003; Zitellini et al., 2004; Terrinha et al., 2009; Martínez-Loriente et al., 2018), the Marquês de Pombal Fault (MPF) (Gràcia et al., 2003; Terrinha et al., 2003; Zitellini et al., 2004), the Gorringe Bank Fault (GBF) (Zitellini et al., 2009; JiménezMunt et al., 2010; Sallarès et al., 2013; Martínez-Loriente et al., 2014) and the Coral Patch Fault (CPF) (MartínezLoriente et al., 2013) (Fig. 1). The GBF and the CPF bound the Horseshoe Abyssal Plain (HAP). The NE-SW-striking thrusts are deep-rooted faults accompanied by morphological seafloor signatures. Moderate- and low-magnitude events $(M<5)$ characterise the seismicity of the area. These faults lie between the Gorringe Bank and the Strait of Gibraltar (Custódio et al., 2015). South of the HAP the Coral Patch ridge was identified to have a northern and a southern segment (Martínez-Loriente et al., 2013).

Other smaller NE-SW-trending structures are the São Vicente Fault (SVF) (Gràcia et al., 2003; Zitellini et al., 2004), the Horseshoe Abyssal Plain Thrust (HAT) (MartínezLoriente et al., 2014) and to the south of the CPF, the Seine Hills (SH) (Martínez-Loriente et al., 2013) (Fig. 1).

The SWIM lineaments (LN and LS) (Fig. 1) have been interpreted as the present-day boundary between the Eurasian and African plates (Zitellini et al., 2009). They are large WNW-ESE-trending dextral strike-slip faults with lengths of $\sim 130$ and $180 \mathrm{~km}$ for the LN and LS respectively. OBS monitoring captured numerous moderate-magnitude seismic events $\left(M_{\mathrm{w}} 3-5\right)$ at the intersection of the SWIM faults and NE-SW-striking thrusts (Geissler et al., 2010; Silva et al., 2017). Ocean floor morphological signatures like en echelon folds and sets of undulations suggest the quaternary reactivation of the deep-rooted basement faults (Terrinha et al., 2009; Rosas et al., 2009). Terrinha et al. (2009) propose that the present-day deformation in the SWIM is accommodated by strain partitioning of dextral wrenching along the SWIM lineaments and thrusting along the NE-SW faults in the Gulf of Cadiz and the HAP. Bartolome et al. (2012) attributes the SWIM faults with the capacity to trigger $M_{\mathrm{w}}>8.0$ earthquakes.

Considering the tectonic structures known today, the CPF is a large-scale fault located closest to the source area of the 1761 event suggested by Baptista et al. (2006). This area, located southwest of the SWIM faults, is in a slow deforming compressive regime driven by the dextral transpressive collision between Africa and Eurasia. Hayward et al. (1999) showed the existence of widespread compressive structures in this region (Coral Patch and Ampere seamounts) based on 


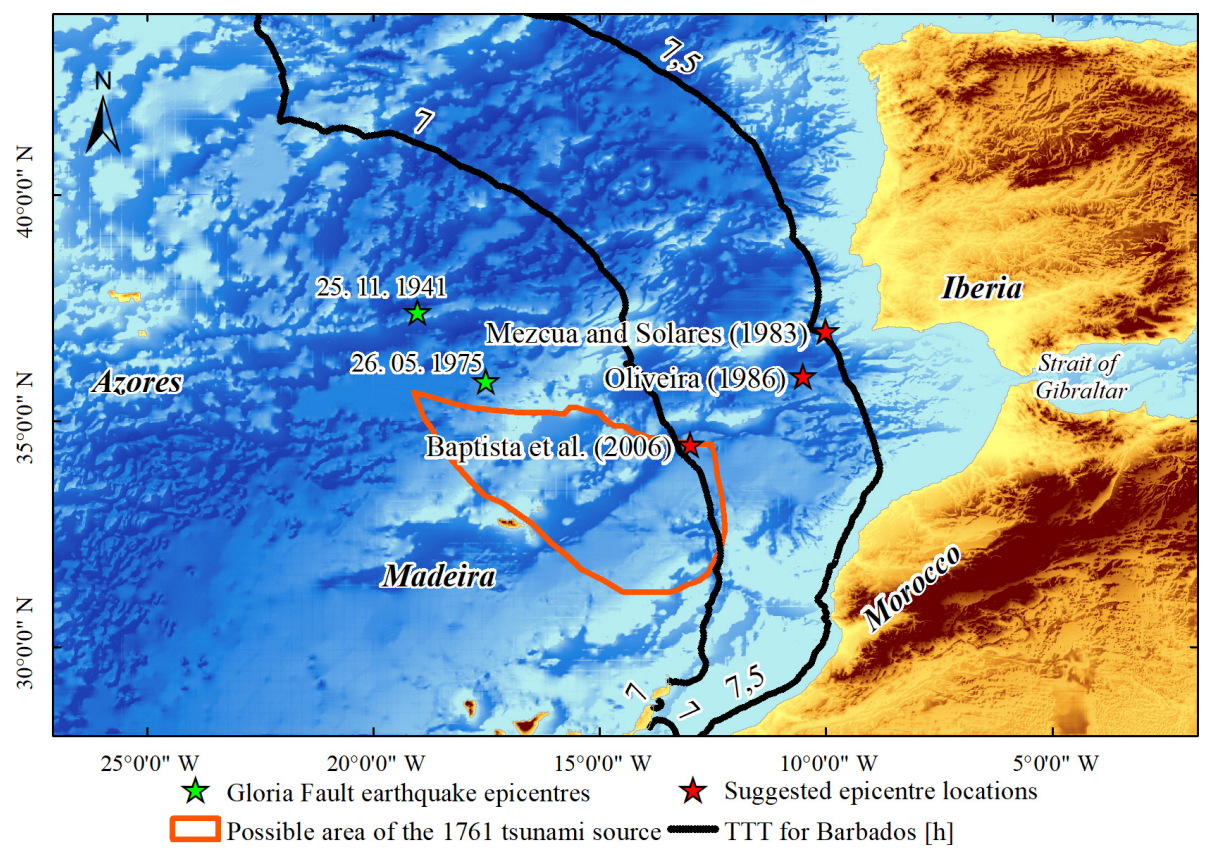

Figure 2. The red stars show the proposed source locations for the 1761 earthquake. The green stars present the epicentres of the two highmagnitude events in the Gloria Fault zone, and the black lines show the backward ray-tracing contours for the tsunami travel time (TTT) of $7-7.5 \mathrm{~h}$ to Barbados. The limited orange area defines the results obtained using macroseismic analysis combined with backward ray tracing but discarding the TTT for Barbados by Baptista et al. (2006).

shallow seismic reflection and side scan sonar data (Figs. 1 and 3). The tectonic deformation uplifted the oceanic crust, showing the pervasive original NE-SW-striking oceanic fabric formed during oceanic rifting (Hayward et al., 1999; Zitellini et al., 2009). The IGN seismic catalogues list a 6.2 magnitude around the Coral Patch on 11 July 1915 (Instituto Geográfico Nacional, 2018).

Kinematic plate models (Argus et al., 1989; DeMets et al., 1999; Nocquet and Calais, 2004; Fernandes et al., 2007) predict low convergence rates $3-5 \mathrm{~mm}_{\text {year }}{ }^{-1}$ between African plates and Eurasia. We used the global kinematic plate model Nuvel-1A. This model is a recalibrated version of the precursor model Nuvel-1 that implements rigid plates and data from plate boundaries such as spreading rates, transform fault azimuths and earthquake slip vectors (DeMets et al., 1990). The NUVEL 1A model predicts a relatively conservative convergence rate of $3.8 \mathrm{~mm} \mathrm{year}^{-1}$ in the area close to the source area determined by Baptista et al. (2006) for the 1761 tsunami (Fig. 2).

Consequently, we propose a fault extending from the western segment of the CPF towards the epicentre proposed by Baptista et al. (2006). We draw the circle around the Euler pole at $-20.61^{\circ} \mathrm{W}, 21.03^{\circ} \mathrm{N}$ according to the plate kinematic model Nuvel 1-A using Mirone suite (Luis, 2007). To do this, we choose Africa as the fixed plate and Eurasia as the moving plate and draw the circle at the centre of the fault in Fig. 3. We compute the convergence rate $\left(3.8 \mathrm{~mm} \mathrm{year}^{-1}\right)$ and plot the tangent velocity vector along the circle (Fig. 3). For this fault, we test different earthquake fault parameters (Table 2) and compute the coseismic deformation using the Mansinha and Smylie equations (Mansinha and Smylie, 1971) implemented in the Mirone suite (Luis, 2007). We assume that the initial sea surface elevation mimics the sea bottom deformation and we use it to initiate the tsunami propagation model.

\section{Reassessment of historical data on the 1761 tsunami}

Baptista et al. (2006) and Baptista and Miranda (2009) present most of the tsunami observations used herein. Here, we focus on the observations of wave heights, periods, inundation and duration of the sea disturbance that we summarise in Table 1. We only reassess the observations in Barbados and Cadiz.

\subsection{Barbados}

Baptista et al. (2006) discarded the arrival time observation in Barbados. However, we find that this is compatible with the source location. The observations report the tsunami arrival at 16:00 local time (Mason, 1761; Annual Register, 1761; Borlase, 1762). If we use a solar time difference between Lisbon and Barbados of $3.5 \mathrm{~h}$, as in Baptista et al. (1998a, b), we conclude a tsunami travel time of $7-7.5 \mathrm{~h}$. To validate this TTT (tsunami travel time), we did a backward ray-tracing simulation with a point source in Barbados (see Figs. 2 and 3) and we find that the TTT is compatible with the source area. 
Table 2. The fault dimensions and parameters used herein investigate candidate sources of the 1761 event. We describe hypotheses (Hyp.) A-MS, A and B by the fault parameters length $(L)$, width $(W)$, strike, dip, rake, slip and depth. The slip values for hypothesis A-MS are listed for each segment from west to east. Additionally, we present the moment magnitude (Mag.), the assumed shear modulus $(\mu)$ and the focal mechanism.

\begin{tabular}{lrrrrrrrrrc}
\hline Scenario & $\begin{array}{r}L \\
(\mathrm{~km})\end{array}$ & $\begin{array}{r}W \\
(\mathrm{~km})\end{array}$ & $\begin{array}{r}\text { Strike } \\
\left({ }^{\circ}\right)\end{array}$ & $\begin{array}{r}\text { Dip } \\
\left({ }^{\circ}\right)\end{array}$ & $\begin{array}{r}\text { Rake } \\
\left({ }^{\circ}\right)\end{array}$ & $\begin{array}{r}\text { Slip } \\
(\mathrm{m})\end{array}$ & $\begin{array}{r}\text { Depth } \\
(\mathrm{km})\end{array}$ & Mag. & $\begin{array}{c}\mu \\
(\mathrm{Pa})\end{array}$ & $\begin{array}{c}\text { Focal } \\
\text { mechanism }\end{array}$ \\
\hline Hyp. A-MS & $4 \times 50$ & 50 & 76 & 40 & 135 & $7 / 15 / 15 / 8$ & 10 & 8.4 & $4 \times 10^{10}$ & $\boldsymbol{O}$ \\
Hyp. A & 200 & 50 & 76 & 40 & 135 & 11 & 10 & 8.4 & $4 \times 10^{10}$ & $\boldsymbol{O}$ \\
Hyp. B & 280 & 50 & 254.5 & 70 & 45 & 15 & 10 & 8.5 & $4 \times 10^{10}$ & $\boldsymbol{\emptyset}$ \\
\hline
\end{tabular}

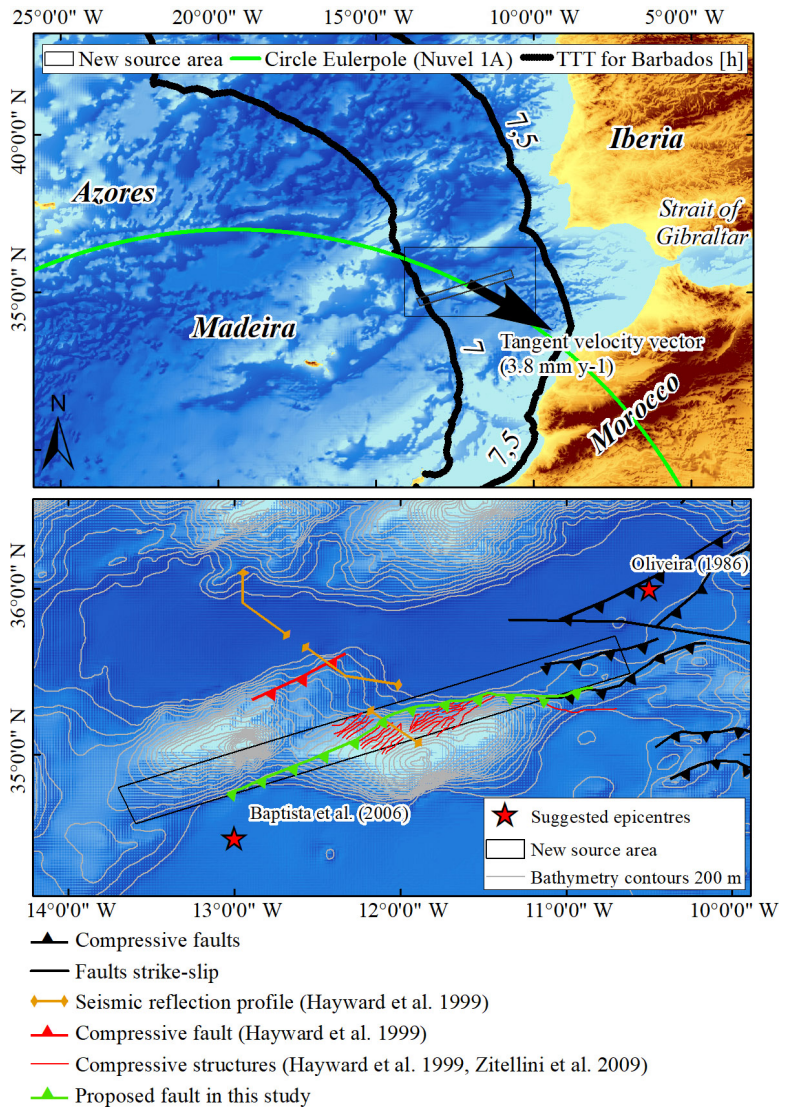

Figure 3. A circle around the Euler pole at the proposed possible source location. The model Nuvel 1A (DeMets et al., 1994, 1999) computes a $3.8 \mathrm{~mm}$ year ${ }^{-1}$ convergence. We plot the tangent velocity vector close to the candidate source. The black lines depict the backward ray-tracing contours in hours, for a tsunami travel time (TTT) of 7-7.5 h to Barbados. In the inset, the black lines plot the thrust and strike-slip faults. The red lines depict the faults and structures proposed in Hayward et al. (1999). The orange lines show the location of the seismic profiles for the areas of the Coral Patch and Ampere seamounts (Hayward et al., 1999). The green line identifies the proposed tectonic structure used in this study. The red stars are the locations of the closest proposed epicentres (Baptista et al., 2006; Oliveira, 1986).

\subsection{Cadiz}

The Journal des Matiéres du Temps (Journal Historique, 1773) describes the occurrence of an earthquake in April 1773 and compares it with the 31 March 1761 event. The report concludes that no tsunami was observed in 1773 and suggests a withdraw of the sea after the 31 March 1761 earthquake in the city; however, there are no accounts of inundation, neither for the city nor for the causeway. We in clude this observation to constrain the proposed source better.

Table 1 presents a summary of all historical data relevant to the tsunami simulation. Figure 1 shows the locations of the tsunami observations. Wave heights always refer to the maximum positive amplitude above the still water level.

\section{Tsunami simulations}

\subsection{The numerical model}

We used the code NSWING (Non-linear Shallow Water model wIth Nested Grids) for numerical tsunami modelling. The code solves linear and non-linear shallow water equations (SWEs) in a Cartesian or spherical reference frame using a system of nested grids and a moving boundary condition to track the shoreline motion based on COMCOT (Cornell Multi-grid Coupled Tsunami Model; Liu et al., 1995, 1998). The code was benchmarked with the analytical tests presented by Synolakis et al. (2008) and tested in Miranda et al. (2014) and Baptista et al. (2016), Wronna et al. (2015) and Omira et al. (2015).

For Cadiz and Lisbon only, where high-resolution bathymetric data were available, we employed a set of coupled nested grids with a final resolution of $25 \mathrm{~m}$ to compute inundation. We compute a new bathymetric data set using the nautical charts close to the coast or lidar data to build a digital elevation model to compute inundation in Lisbon and Cadiz. Close to the tsunami source we interpolate bathymetry data (GEBCO, 2014) to obtain a $1600 \mathrm{~m}$ grid cell size. We apply a refinement factor of 4 for the four nested grids. Consequently, the intermediate grids have a resolution of $100 \mathrm{~m}$ 
Table 3. Results of the VTGs for hypothesis A-MS. The column TTT lists the observed tsunami travel times. The column polarity indicates the first movement of the sea upward (U) or downward (D).

\begin{tabular}{|c|c|c|c|c|c|c|c|c|c|c|c|}
\hline \multirow[t]{2}{*}{ Local } & & \multicolumn{3}{|c|}{ VTG coordinates and depth } & \multirow[t]{2}{*}{ TTT } & \multicolumn{4}{|c|}{ Wave height (m) } & \multirow[t]{2}{*}{ Polarity } & \multirow[t]{2}{*}{ Period } \\
\hline & & long. $\left({ }^{\circ}\right)$ & lat. $\left({ }^{\circ}\right)$ & $d(\mathrm{~m})$ & & first & $\max$ & Green's law & observation & & \\
\hline Lisbon & & -9.136 & 38.706 & 3 & $\sim 1 \mathrm{~h} 10 \mathrm{~min}$ & $1.6 \mathrm{~m}$ & $1.8 \mathrm{~m}$ & nesting & $1.2-1.8 \mathrm{~m}$ & $\mathrm{D}$ & $<30 \mathrm{~min}$ \\
\hline Cadiz & & -6.291 & 36.524 & 4 & $\sim 1 \mathrm{~h}$ & $-0.6 \mathrm{~m}$ & $2.4 \mathrm{~m}$ & nesting & - & $\mathrm{D}$ & $\sim 30 \mathrm{~min}$ \\
\hline Isles of Scilly & & -06.383 & 49.85 & 50 & $\sim 4 \mathrm{~h}$ & $0.4 \mathrm{~m}$ & $0.4 \mathrm{~m}$ & $0.7 \mathrm{~m}$ & $0.6-1.2 \mathrm{~m}$ & $\mathrm{U}$ & $\sim 15 \min$ \\
\hline Mount's Bay & & -05.48 & 50.08 & 26 & $\sim 4 \mathrm{~h} 30 \mathrm{~min}$ & $0.4 \mathrm{~m}$ & $0.5 \mathrm{~m}$ & $0.8 \mathrm{~m}$ & $1.2-1.8 \mathrm{~m}$ & $\mathrm{U}$ & $\sim 15 \mathrm{~min}$ \\
\hline Kinsale & & -08.500 & 51.653 & 28 & $\sim 4 \mathrm{~h} 15 \mathrm{~min}$ & $0.1 \mathrm{~m}$ & $0.5 \mathrm{~m}$ & $0.8 \mathrm{~m}$ & $0.6 \mathrm{~m}$ & $\mathrm{U}$ & $<15 \min$ \\
\hline Dungarvan & & -07.479 & 51.949 & 50 & $\sim 5 \mathrm{~h}$ & $0.1 \mathrm{~m}$ & $0.3 \mathrm{~m}$ & $0.5 \mathrm{~m}$ & - & $\mathrm{U}$ & $<15 \mathrm{~min}$ \\
\hline \multirow{2}{*}{ Madeira } & $\mathrm{E}$ & -16.666 & 32.750 & 51 & $\sim 30 \mathrm{~min}$ & $0.3 \mathrm{~m}$ & $0.8 \mathrm{~m}$ & $1.4 \mathrm{~m}$ & - & $\mathrm{U}$ & $\sim 30 \mathrm{~min}$ \\
\hline & $\mathrm{S}$ & -16.926 & 32.619 & 51 & $\sim 40 \mathrm{~min}$ & $0.2 \mathrm{~m}$ & $0.4 \mathrm{~m}$ & $0.7 \mathrm{~m}$ & - & $\mathrm{U}$ & $\sim 30 \mathrm{~min}$ \\
\hline Azores & & -27.150 & 38.800 & 53 & $\sim 2 \mathrm{~h}$ & $0.5 \mathrm{~m}$ & $0.7 \mathrm{~m}$ & $1.3 \mathrm{~m}$ & - & $\mathrm{U}$ & $\sim 15 \mathrm{~min}$ \\
\hline Barbados & & -59.566 & 13.033 & 50 & $\sim 7 \mathrm{~h}$ & $0.1 \mathrm{~m}$ & $0.2 \mathrm{~m}$ & $0.4 \mathrm{~m}$ & $0.45-0.6 \mathrm{~m}$ & $\mathrm{U}$ & $\sim 30 \mathrm{~min}$ \\
\hline
\end{tabular}

and $400 \mathrm{~m}$ respectively. In Cadiz, we use the soundings and coastline of historical nautical charts from the 18th century (Bellin, 1762; Rocque, 1762) to compute a palaeo digital elevation model (PDEM) (Wronna et al., 2017). To do this, we georeferenced the old nautical charts and used the modernday DEM (UG-ICN, 2009) to implement the information from the historical charts. According to Wronna et al. (2017), we systematically remodelled bathymetry and the coastline.

To initiate the tsunami propagation model, we compute the coseismic deformation according to the half-space elastic theory (Mansinha and Smylie, 1971) implemented in the Mirone suite (Luis, 2007). Assuming that water is an incompressible fluid, we translate the sea bottom deformation to the initial sea surface deformation and set the velocity field to zero for the time instant $t=0 \mathrm{~s}$. We run the model for $10 \mathrm{~h}$ propagation time to ensure that the tsunami reaches all observation points, with the bathymetric model referenced to mean sea level.

We compute the offshore wave heights for points located close to the observation points (Fig. 1) using virtual tide gauges (VTGs). We include the coordinates and depths of the VTGs in Tables 3 and 4 in Sect. 5. For transatlantic propagation, we consider the Coriolis effect in the tsunami simulation. We checked all tsunami simulations against historical data.

For the locations in Ireland, the United Kingdom, the Azores, Madeira and Barbados, we estimate the wave heights near the shore using Green's law (Green, 1838), following Hebert and Schindelé (2015) and Davies et al. (2018). Hebert and Schindelé (2015) concluded that the extrapolation for depths between 10 and $1 \mathrm{~m}$ generally allowed for a good fit with the observations for the 2004 Indian Ocean tsunami. Green's law is based on the linear shallow water wave equations and allows us to quickly approximate the amplification of wave heights at a shallower depth close to the shore when considering a plane beach. The wave height increases to the fourth root of the ratio between the depth at the shore and the water depth at the VTG. We extrapolate the maximum wave height values between the depths of the VTGs (Tables 3 and 4) to points located at $5 \mathrm{~m}$ depth.

$h_{\mathrm{s}}=\sqrt[4]{\frac{d_{\mathrm{s}}}{d_{\mathrm{d}}}} \cdot h_{\mathrm{d}}$,

where $h_{\mathrm{s}}$ and $h_{\mathrm{d}}$ are the wave heights at the shore and the VTGs, and $d_{\mathrm{s}}$ and $d_{\mathrm{d}}$ are the depths at the shore and the VTGs. We use a constant value of $5 \mathrm{~m}$, which is sufficiently close to the shore to be observed by eyewitnesses. The results of the approximation according to Green's law are presented in Tables 3 and 4.

\subsection{Testing the hypothesis}

In the 20th century, two high-magnitude earthquakes occurred in the Gloria Fault (GF) area. Because of this, we tested the compatibility of the tsunami observations in 1761 with the tsunamis produced by the earthquakes of the 25 November 1941 (Lynnes and Ruff, 1985; Baptista et al., 2016) and 26 May 1975 (Kaabouben et al., 2009, Fig. 2). We use the fault plane parameters and rupture mechanism presented in Baptista et al. (2016) and Kaabouben et al. (2008) for the 1941 and 1975 events respectively. The fault dimensions and slip were made compatible with an 8.5 magnitude event using the scaling laws proposed by Wells and Coppersmith (1994), Manighetti et al. (2007), Blaser et al. (2010) and Matias et al. (2013).

These two events produce less than a $1 \mathrm{~m}$ wave height in the north-east Atlantic and a barely observed wave in the Caribbean islands (Baptista et al., 2016, 2017). Moreover, the epicentres of the 25 November 1941 and 26 May 1975 events are located outside the area determined by Baptista et al. (2006). As expected, the TTTs do not agree with those reported in 1761; therefore, we excluded the GF as a candidate source for the 1761 event and do not consider their results for discussion.

The candidate fault area is centred at $12.00^{\circ} \mathrm{W}, 35.00^{\circ} \mathrm{N}$ to the west of the large NE-SW-striking compressive struc- 
Table 4. Results of the VTGs for hypothesis B. The column TTT lists the observed tsunami travel times. The column polarity indicates the first movement of the sea upward (U) or downward (D).

\begin{tabular}{|c|c|c|c|c|c|c|c|c|c|c|c|}
\hline \multirow[t]{2}{*}{ Local } & & \multicolumn{3}{|c|}{ VTG coordinates and depth } & \multirow[t]{2}{*}{ TTT } & \multicolumn{4}{|c|}{ Wave height (m) } & \multirow[t]{2}{*}{ Polarity } & \multirow[t]{2}{*}{ Period } \\
\hline & & long. $\left({ }^{\circ}\right)$ & lat. $\left({ }^{\circ}\right)$ & $d(\mathrm{~m})$ & & first & $\max$ & Green's law & observation & & \\
\hline Lisbon & & -9.136 & 38.706 & 3 & $\sim 1 \mathrm{~h} 15 \mathrm{~min}$ & $0.9 \mathrm{~m}$ & $2.2 \mathrm{~m}$ & nesting & $1.2-1.8 \mathrm{~m}$ & $\mathrm{D}$ & $>30 \mathrm{~min}$ \\
\hline Cadiz & & -6.291 & 36.524 & 4 & $\sim 1 \mathrm{~h}$ & $-0.4 \mathrm{~m}$ & $2.6 \mathrm{~m}$ & nesting & - & $\mathrm{D}$ & $\sim 30 \mathrm{~min}$ \\
\hline Isles of Scilly & & -06.383 & 49.85 & 50 & $<4 \mathrm{~h} \min$ & $0.4 \mathrm{~m}$ & $0.5 \mathrm{~m}$ & $0.9 \mathrm{~m}$ & $0.6-1.2 \mathrm{~m}$ & $\mathrm{U}$ & $\sim 15 \mathrm{~min}$ \\
\hline Mount's Bay & & -05.48 & 50.08 & 26 & $\sim 4 \mathrm{~h} 30 \mathrm{~min}$ & $0.4 \mathrm{~m}$ & $0.7 \mathrm{~m}$ & $1 \mathrm{~m}$ & $1.2-1.8 \mathrm{~m}$ & $\mathrm{U}$ & $\sim 15 \mathrm{~min}$ \\
\hline Kinsale & & -08.500 & 51.653 & 28 & $\sim 4 \mathrm{~h} 15 \mathrm{~min}$ & $0.2 \mathrm{~m}$ & $0.6 \mathrm{~m}$ & $1 \mathrm{~m}$ & $0.6 \mathrm{~m}$ & $\mathrm{U}$ & $<15 \min$ \\
\hline Dungarvan & & -07.479 & 51.949 & 50 & $\sim 5 \mathrm{~h}$ & $0.1 \mathrm{~m}$ & $0.4 \mathrm{~m}$ & $0.7 \mathrm{~m}$ & - & $\mathrm{U}$ & $<15 \min$ \\
\hline \multirow{2}{*}{ Madeira } & $\mathrm{E}$ & -16.666 & 32.750 & 51 & $\sim 30 \mathrm{~min}$ & $0.9 \mathrm{~m}$ & $1.4 \mathrm{~m}$ & $2.5 \mathrm{~m}$ & - & $\mathrm{U}$ & $\sim 30 \mathrm{~min}$ \\
\hline & $\mathrm{S}$ & -16.926 & 32.619 & 51 & $\sim 40 \mathrm{~min}$ & $0.3 \mathrm{~m}$ & $1.1 \mathrm{~m}$ & $2.1 \mathrm{~m}$ & - & $\mathrm{U}$ & $\sim 30 \mathrm{~min}$ \\
\hline Azores & & -27.150 & 38.800 & 53 & $\sim 1 \mathrm{~h} 45 \mathrm{~min}$ & $0.5 \mathrm{~m}$ & $2.4 \mathrm{~m}$ & $4.2 \mathrm{~m}$ & - & $\mathrm{U}$ & $\sim 15 \mathrm{~min}$ \\
\hline Barbados & & -59.566 & 13.033 & 50 & $\sim 7 \mathrm{~h}$ & $0.1 \mathrm{~m}$ & $0.6 \mathrm{~m}$ & $1.1 \mathrm{~m}$ & $0.45-0.6 \mathrm{~m}$ & $\mathrm{U}$ & $\sim 30 \mathrm{~min}$ \\
\hline
\end{tabular}

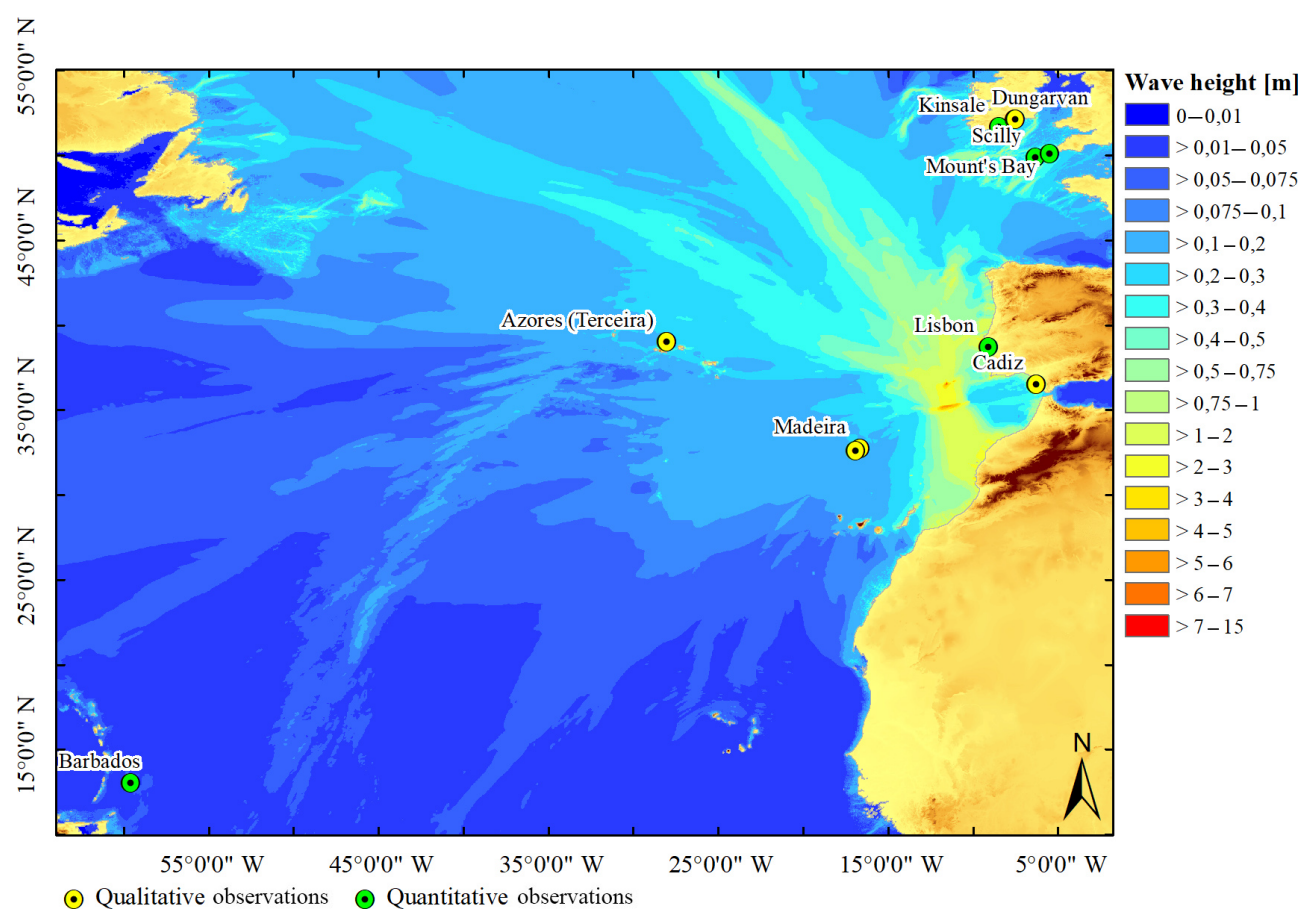

Figure 4. Maximum wave height distribution (colour scale in metres) in the Atlantic basin produced by the source of hypothesis A-MS.

tures (Martínez-Loriente et al., 2013) and $85 \mathrm{~km}$ northeast of the epicentre suggested by Baptista et al. (2006) (Fig. 3). We considered the fact that the historical accounts indicate an earthquake and tsunami less violent than in 1755 . To account for this, we used the fault dimensions presented in Table 2 corresponding to a magnitude 8.4-8.5 earthquake (Baptista et al., 2006); consequently, the wave heights in Lisbon and Cadiz are smaller than those observed in the 1755 tsunami (Baptista et al., 1998). The fault dimensions (length and width) presented in Table 2 are compatible with the scaling laws of Wells and Coppersmith (1994), Manighetti et al. (2007), Blaser et al. (2010) and Matias et al. (2013).

\subsubsection{Hypotheses A and A-MS}

Here we use a strike angle compatible with the study by Martínez-Loriente et al. (2013), which follows the morphology of the Coral Patch scarp and seamount (Figs. 1 and 3). To take into account the tectonic regime of the source area we choose fault plane parameters compatible with a structure of compressive nature. The velocity vector predicted by NUVEL 1A (Fig. 3), together with the short tsunami wave periods (4-12 $\mathrm{min}$ ) reported in 1761 (Table 1), are in line with the chosen dip angle of $40^{\circ}$ (Table 2). On the other hand, Martínez-Loriente et al. (2013) suggest for the Coral Patch Fault dip angles of $30 \pm 5^{\circ}$ and a rake angle of $90^{\circ}$. These authors also conclude that the fault root is between 7 and $13 \mathrm{~km}$ 

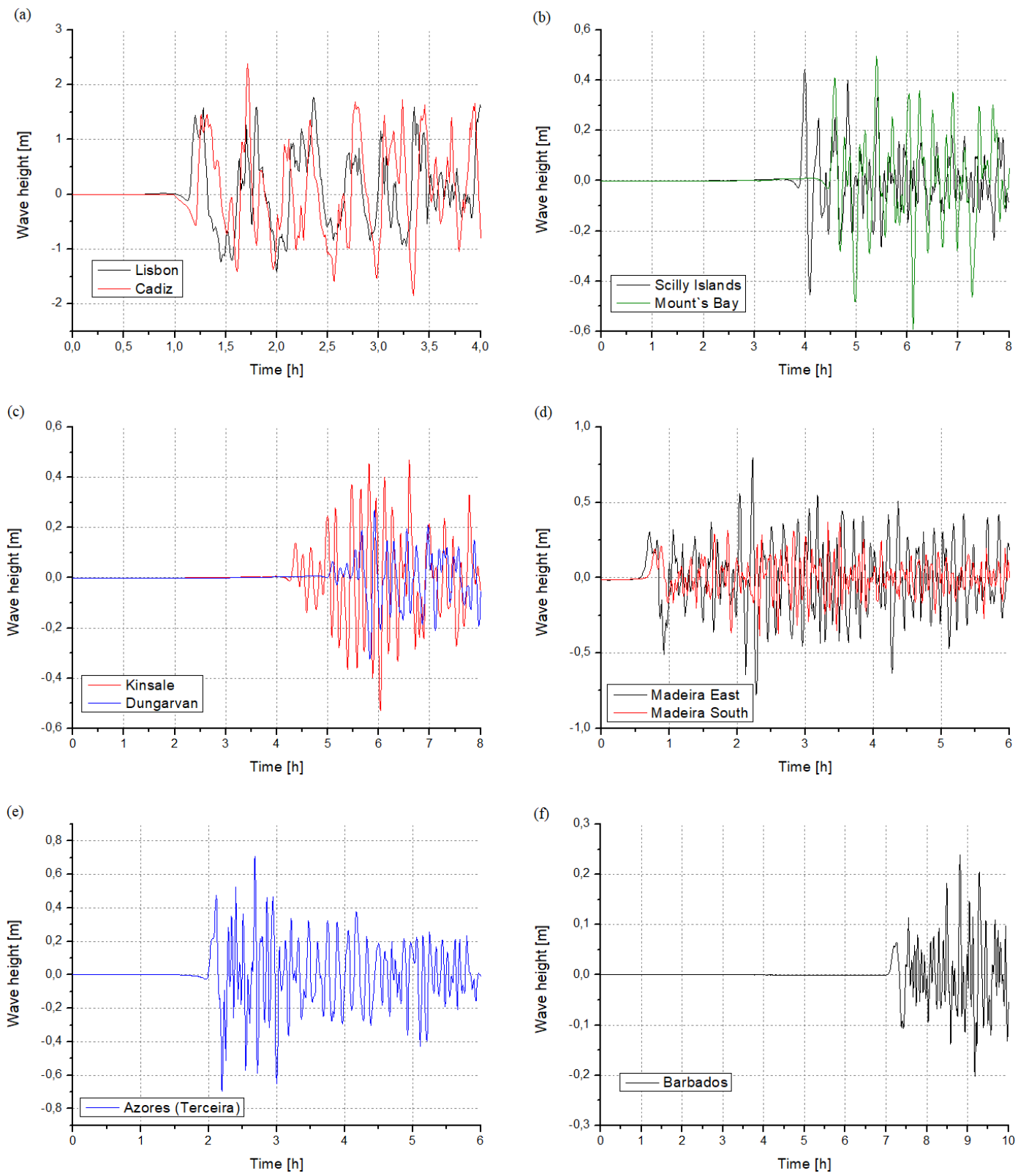

Figure 5. VTG records for hypothesis A-MS at the coordinates of the locations presented in Table 3.

depth. We approximate the rake angle according to the difference between the convergence arrow given by the circle around the Euler Pole and the fault plane (Fig. 3).

The wave period in Lisbon produced by this candidate source is $30 \mathrm{~min}$. This value is not compatible with the observations (Table 1). By trying to solve this problem, we implemented a multi-segment fault here called A-MS. This multi-segment solution consists of four segments, each of which are $50 \mathrm{~km}$. The four segments are placed adjacent to each other, and the rupture mechanism is equal for each segment as in hypothesis A with a mean slip of $11 \mathrm{~m}$ (Table 2). To investigate the slip distribution, we tested three setups:
(1) maximum slip towards the SW, (2) maximum slip towards the NE and (3) maximum slip close to the centre of the fault. In the first setup, the observed withdrawal of the sea in Cadiz is less evident and produces little inundation in Lisbon; in the second setup there is inundation at Cadiz, which is not supported by historical data. All these results led us to select the maximum slip at the centre of the fault. The slip of each segment is presented in Table 2. The synthetic waveforms are presented in Fig. 5 and discussed in Sects. 5 and 6. 


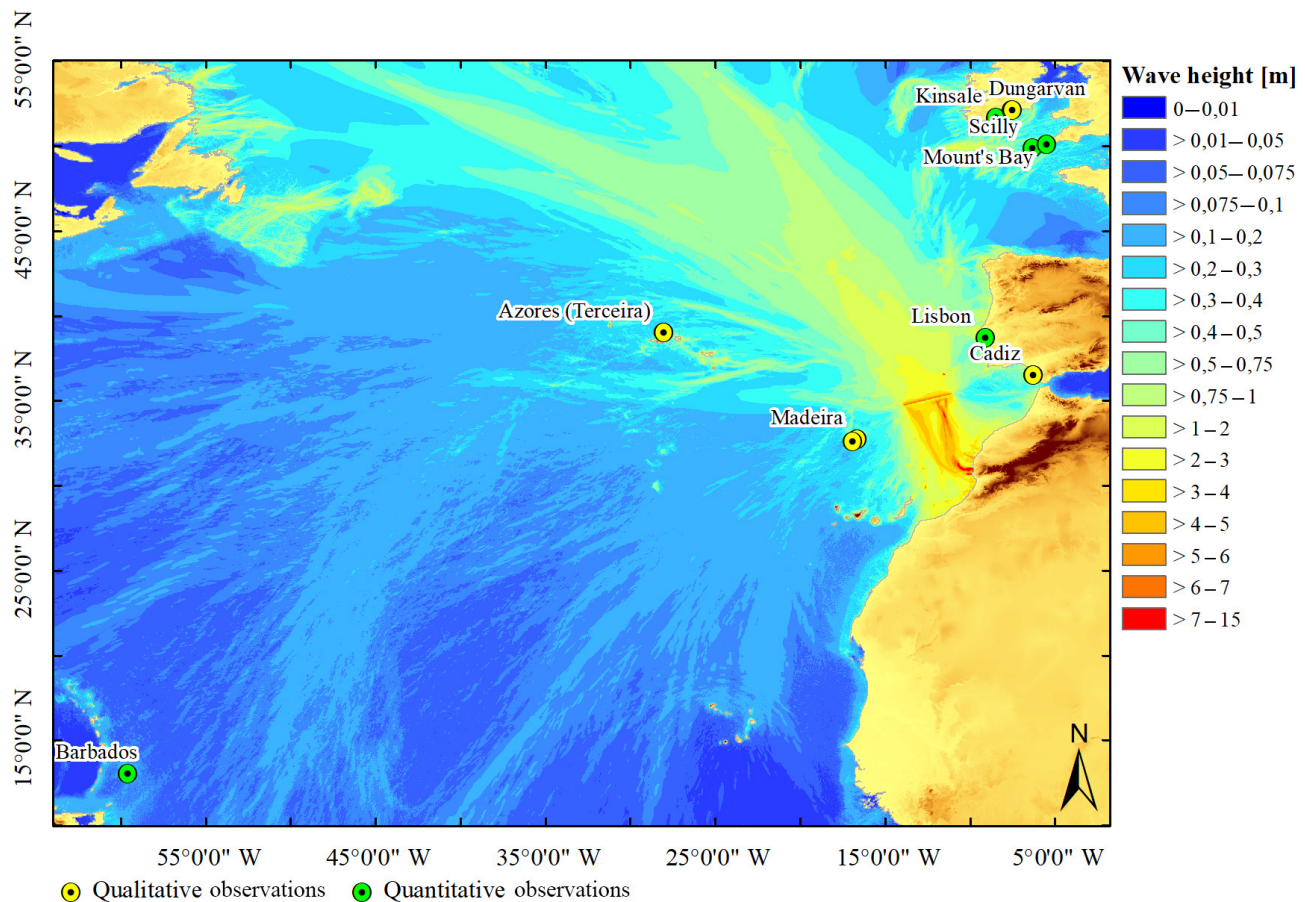

Figure 6. Maximum wave height distribution (colour scale in $\mathrm{m}$ ) in the Atlantic basin produced by the source of hypothesis B.

\subsubsection{Hypothesis B}

Finally, we test an alternative hypothesis here, called B, which has a larger strike-slip component compared to hypothesis A. This also results in a larger fault length and a steeper dip angle. Here, we consider a rupture along a fault plane rotated about $180^{\circ}$ when compared to hypothesis A. To do this, we selected compatible strike and rake angles that result in a sinistral inverse lateral rupture (Table 2). The implementation of the different setups of slip distribution in solution B does not improve the quality of the results; therefore we only consider a single segment fault for this hypothesis. The synthetic waveforms are presented in Fig. 7 and discussed in Sects. 5 and 6.

\section{Results}

We present the results of hypotheses A-MS and B. Hypothesis A-MS has a more significant inverse component compared to hypothesis B. Once the results of hypotheses A and A-MS produce same wave height values, but the latter produces shorter periods, we opt to present the results for hypothesis A-MS. Figures 4-7 show the maximum wave height and the synthetic tsunami at the virtual tide gauges (VTGs) computed offshore of each observation point of hypothesis A-MS and B. Tables 3 and 4 summarise these results. The wave height, as mentioned in Sect. 3, represents the maximum positive amplitude above the still water level, which is set to mean sea level in the tsunami simulation. Tables 3 and 4 present the geographical coordinates and depths of the VTGs. To compare the synthetic wave heights with the observations for the locations in Mount's Bay, Isles of Scilly, Kinsale, Dungarvan, Azores, Madeira and Barbados, we used Green's law (Green, 1838) to extrapolate the wave height values for the maximum wave between the depths of the VTGs to points located at $5 \mathrm{~m}$ depth. For Lisbon and Cadiz, where high-resolution bathymetry is available, we used two sets of nested grids and computed the tsunami inundation. Here the VTGs are located close to the shore, and the application of Green's law is not necessary.

\subsection{Hypothesis A-MS}

Figures 4 and 5 show the distribution of the maximum wave height and the respective synthetic tsunami records for hypothesis A-MS.

The analysis of Fig. 4 shows wave heights exceeding $4 \mathrm{~m}$ in the Gulf of Cadiz. At some points along the coast of Morocco maximum wave heights are about $5 \mathrm{~m}$. In Great Britain, at the Isles of Scilly and Mount's Bay, maximum wave heights vary between 1.7 and $1.9 \mathrm{~m}$. Along the south coast of Ireland, in Kinsale and Dungarvan, the tsunami simulation predicts a $1 \mathrm{~m}$ maximum wave height. At the eastern coast of the island of Madeira, the wave heights reach $1 \mathrm{~m}$, whereas on the southern part of the island the wave heights are smaller. At the Azores, close to Terceira, wave heights are slightly higher than $2.5 \mathrm{~m}$ along the south coast of the island. The wave heights in the south of Barbados reach $0.5 \mathrm{~m}$. 
(a)
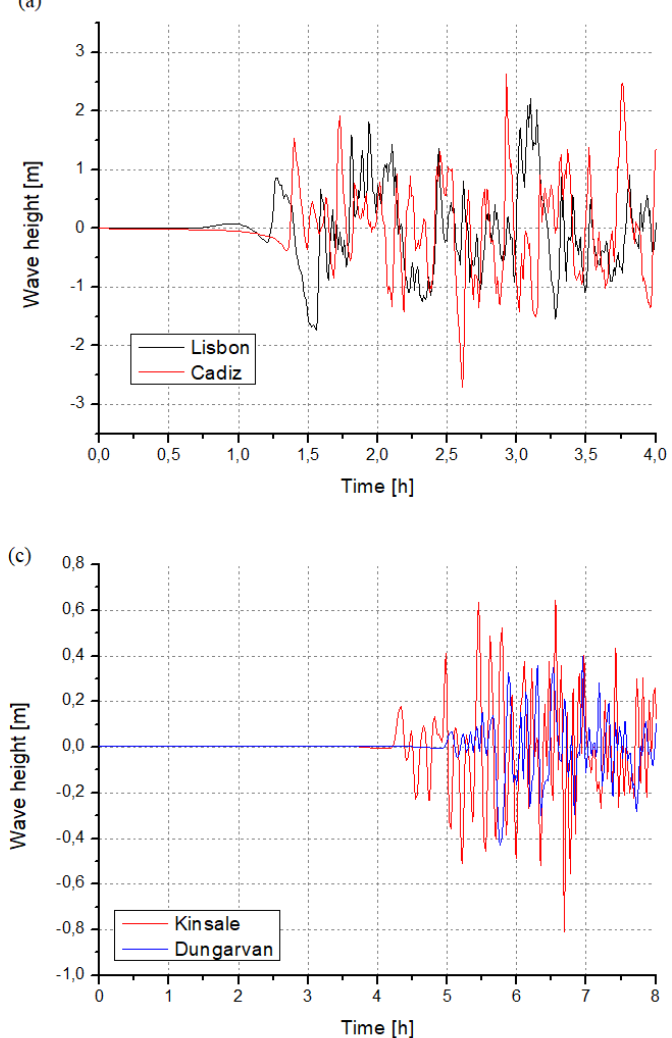

(e)

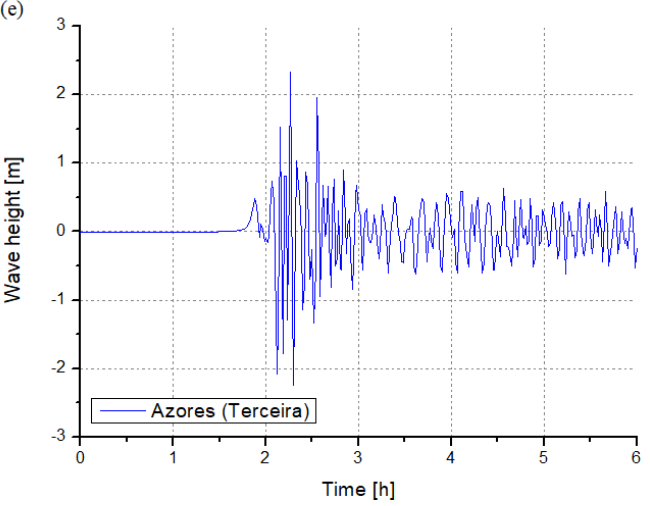

(b)
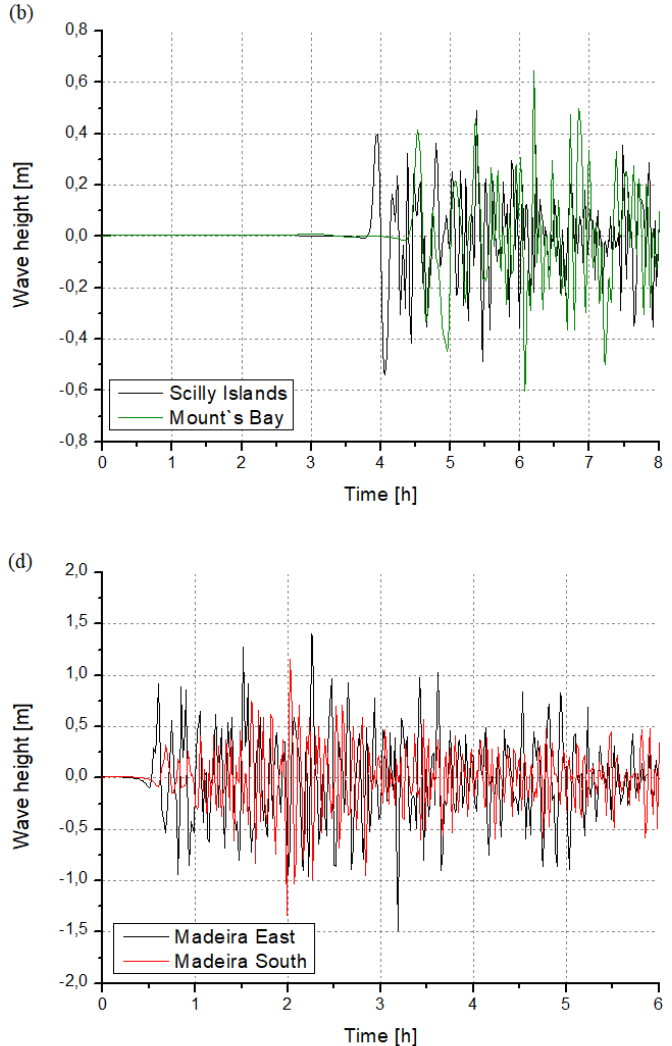

(f)

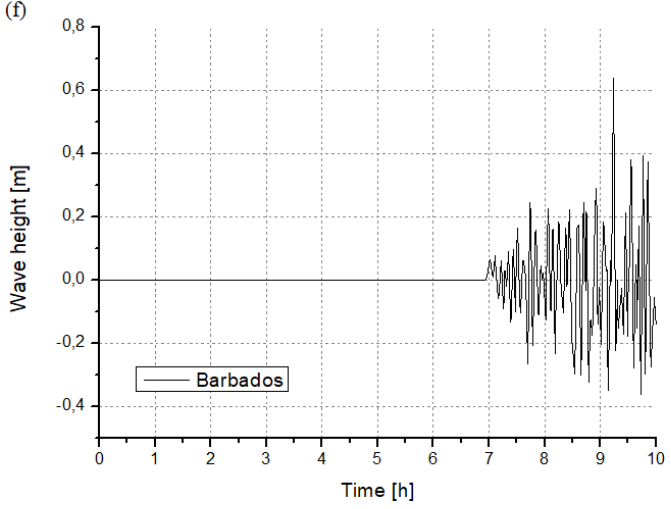

Figure 7. VTG records for hypothesis B at the coordinates of the locations presented in Table 4.

In Lisbon, the synthetic waveform shows a first peak of $1.4 \mathrm{~m}$ with a maximum value close to $1.8 \mathrm{~m}$ for the third wave, after $2 \mathrm{~h}$ and $20 \mathrm{~min}$ of tsunami propagation. The TTT to Lisbon is $1 \mathrm{~h}$ and $10 \mathrm{~min}$ and the first wave has a period of 20-25 min (Table 3 and Fig. 5a). In Cadiz, the synthetic tsunami waveform shows a drawdown $1 \mathrm{~h}$ after the earthquake with a negative amplitude of $0.6 \mathrm{~m}$ and a maximum wave height of $2.4 \mathrm{~m}$ (Table 3 and Fig. 5a).

The Isles of Scilly synthetic tsunami waveform shows a TTT of $4 \mathrm{~h}$ and a maximum peak exceeding $0.4 \mathrm{~m}$ with $15 \mathrm{~min}$ period. In Mount's Bay, TTT is $4 \mathrm{~h}$ and $30 \mathrm{~min}$ and the maximum wave height is $0.5 \mathrm{~m}$ with a $15 \mathrm{~min}$ period. In Kin- sale, the tsunami model computes a TTT of $4 \mathrm{~h}$ and $15 \mathrm{~min}$. The maximum wave height there is about $0.5 \mathrm{~m}$ with a period shorter than $15 \mathrm{~min}$. In Dungarvan, the tsunami arrives $5 \mathrm{~h}$ after the earthquake. All VTGs in northern Europe recorded the first wave as the leading elevation wave (Fig. 5b, c).

In Madeira, hypothesis A-MS produces maximum wave heights at the VTG of $0.8 \mathrm{~m}$ in the eastern part of the island and about $0.4 \mathrm{~m}$ in the southern part; the TTT to the east and southern coast of the island is half an hour and $40 \mathrm{~min}$ respectively (Fig. 5d). In the Azores, close to the island of Terceira, the wave heights reach approximately $0.7 \mathrm{~m}$ (Fig. 5e). 
In Barbados, hypothesis A-MS produces the first wave of about $0.1 \mathrm{~m}$ after about $7 \mathrm{~h}$ with about a $30 \mathrm{~min}$ period. Only after $9 \mathrm{~h}$ and $30 \mathrm{~min}$ does the wave height exceed $0.2 \mathrm{~m}$ (Fig. 5f).

We applied Green's law in all locations except Lisbon and Cadiz to extrapolate the maximum wave height values to a depth of $5 \mathrm{~m}$ close to the shore to compare the values with the observations in Sect. 3. We present the maximum wave height values after the application of Green's law in Table 3.

\subsection{Hypothesis B}

In hypothesis B, the dip angle was increased relative to hypothesis A, resulting in the dominant strike-slip mechanism. In Fig. 6, we depict the maximum wave height for option B.

By analysing Fig. 6 we find maximum wave heights of $15 \mathrm{~m}$ along the coast of Morocco. In the Gulf of Cadiz, the wave heights do not exceed $2 \mathrm{~m}$. In Great Britain, at the Isles of Scilly the maximum wave height is close to $2.3 \mathrm{~m}$, and in Mount's Bay, the maximum wave height values reach $1.8 \mathrm{~m}$. For the locations in Ireland, Kinsale and Dungarvan, the maximum wave heights exceed $1.4 \mathrm{~m}$. The eastern part of Madeira experiences wave heights greater than $2.5 \mathrm{~m}$, decreasing towards the southern parts of the island (Fig. 6). The maximum wave height exceeds $5.5 \mathrm{~m}$ on the eastern side of the island of Terceira in the Azores. For Barbados, this source computes maximum wave heights exceeding $0.7 \mathrm{~m}$.

Figure 7 presents the corresponding synthetic tsunami waveforms at the VTGs. Table 4 gives a summary of the results. The analysis of the synthetic waveforms shows that a small withdraw of about $0.2 \mathrm{~m}$ arrives in Lisbon after $1 \mathrm{~h}$ and $15 \mathrm{~min}$ followed by a water surface elevation of $0.9 \mathrm{~m}$. The third wave has a maximum positive amplitude of $2.2 \mathrm{~m}$ (Fig. 7a).

The maximum wave height at the Isles of Scilly is $0.5 \mathrm{~m}$ (Fig. 7b). The first wave reaches $0.4 \mathrm{~m}$, arriving close to $4 \mathrm{~h}$ after the earthquake. The synthetic tsunami waveform shows around a 15 min wave period. In Mount's Bay, the first wave of $0.4 \mathrm{~m}$ arrives after $4 \mathrm{~h}$ and $30 \mathrm{~min}$ with a $15 \mathrm{~min}$ wave period (Fig. 7b). Here, the maximum wave height, $0.7 \mathrm{~m}$, comes more than $6 \mathrm{~h}$ after the earthquake. In Kinsale, hypothesis B produces a maximum wave height of $0.6 \mathrm{~m}$. The first wave of $0.2 \mathrm{~m}$ wave height in the VTG arrives after $4 \mathrm{~h}$ and $15 \mathrm{~min}$ of tsunami propagation; here, the period is shorter than $15 \mathrm{~min}$ (Fig. 7c).

In Madeira, the first and the maximum wave heights are greater in the eastern part of the island compared to the southern part. Maximum wave heights values reach $1.4 \mathrm{~m}$ in the eastern part of Madeira and $1.1 \mathrm{~m}$ in the southern part of Madeira (Fig. 7d). In the Azores, the wave height for Terceira reaches up to $2.4 \mathrm{~m}$ (Fig. 7e).

Hypothesis B predicts a tsunami travel time of $7 \mathrm{~h}$ to Barbados with the first peak of less than $0.1 \mathrm{~m}$ and a maximum peak of $0.6 \mathrm{~m}$ after $9 \mathrm{~h}$ and $15 \mathrm{~min}$ (Fig. 7f). The first wave has a period slightly below 15 min. Table 4 gives a summary of the results for hypothesis B.

We also applied Green's law for this solution. We present the maximum wave height values after the application of Green's law in Table 4.

\section{Discussion}

We investigated possible sources of the earthquake and tsunami on the 31 March 1761 earthquake in the Atlantic.

Firstly, we excluded the locations similar to the instrumental events of the 20th century: 25 November 1941 (Baptista et al., 2016) and 26 May 1975 (Kaabouben et al., 2009) because of the incompatibility of tsunami travel times (Fig. 2).

Secondly, we placed a source about $85 \mathrm{~km}$ to the east of the location proposed by Baptista et al. (2006) (Fig. 2).

After setting the source position, we investigated focal mechanisms for the parent earthquake. We selected two focal mechanisms for testing: A and B. Solution A-MS corresponds to focal mechanism $\mathrm{A}$ with a multi-segment fault plane as described in Sect. 4.2 (Table 2).

Our tests produce a set of TTTs compatible with the observations: maximum differences between observed and predicted travel times are $15 \mathrm{~min}$ in the near-field and $30 \mathrm{~min}$ in the far-field. These differences are acceptable considering that the exact location of the observation points is unknown. Travel time results are valid for A, B and A-MS, as the locations are the same. Tables 3 and 4 show that the predicted travel times are compatible with a source located in the area west of the Coral Patch.

Any source located in the northeastern Atlantic, south of the Isles of Scilly, produces a shorter tsunami travel time to Scilly than Mount's Bay. This fact shows that the $6 \mathrm{~h}$ TTT reported in Kinsale contradicts the $4 \mathrm{~h}$ TTT reported for Dungarvan (Fig. 1). On the other hand, the tsunami travel times predicted by our numerical simulation are consistent with their position related to the source area. The proposed source A produces wave heights applying Green's law to the values recorded at the VTGs, which are compatible with the observations in Lisbon, Kinsale, Scilly and Barbados (Fig. 5 and Table 3). The results of the synthetic wave records of Dungarvan, Madeira and the Azores are compatible with the observations. In Mount's Bay, the wave height computed using Green's law of the VTG value is smaller than the one reported. However, the analysis of Fig. 4 shows that the computed maximum wave heights are greater than $1.6 \mathrm{~m}$ for Mount's Bay. This value agrees with the observation.

The proposed source B produces wave heights compatible with the observation in Lisbon, Scilly and Mount's Bay. We apply Green's law (Eq. 1) using the wave heights recorded at the VTG in Kinsale and Barbados and obtain larger wave heights than reported (Table 4). Also, the computed maximum wave heights in Fig. 6 are higher than 1.4, 2.2 and $0.7 \mathrm{~m}$ for Kinsale, Scilly and Barbados respectively. These 
Table 5. Tide levels at the time of the earthquake and tsunami arrival.

\begin{tabular}{lclc}
\hline & Time & Tide condition & $\begin{array}{c}\text { Estimated height relative } \\
\text { to hydrographic zero }\end{array}$ \\
\hline Earthquake & Noon & Full tide & $2.9 \mathrm{~m}$ \\
Tsunami arrival time & $13: 15$ & Dropping tide & $2.6 \mathrm{~m}$ \\
Max wave height hypothesis AMS & $14: 15$ & Dropping tide & $2.3 \mathrm{~m}$ \\
Max wave height hypothesis B & $15: 00$ & Dropping tide & $2.1 \mathrm{~m}$ \\
\hline
\end{tabular}

values are higher than the ones observed. At the Azores, the wave height reaches $4.2 \mathrm{~m}$ (Table 4); however, the descriptions do not report an inundation. Also, at the coast of Morocco, source B predicts wave heights close to $14 \mathrm{~m}$. To our knowledge, the historical documents do not report any abnormal movement of the sea in Morocco.

The observations do not account for inundation in Lisbon. To investigate this fact, we estimated the tide condition in Lisbon for 31 March 1761. To do this, we used a Moon phase table (USNO, 2017) and concluded that the tide was $2.6 \mathrm{~m}$ above hydrographic zero (HZ) (in dropping tide conditions) at 13:00 on 31 March 1761 (Table 5).

The maximum of the synthetic wave record for source AMS is $1.8 \mathrm{~m}$ about $2 \mathrm{~h}$ and $15 \mathrm{~min}$ when the tide dropped below $2.3 \mathrm{~m}$ above HZ. Adding 1.8 to $2.3 \mathrm{~m}$, we obtain $4.1 \mathrm{~m}$; this value is less than the tide amplitude in the springtide condition. Considering that the centre of Lisbon was rebuilt $3 \mathrm{~m}$ above sea level after the 1755 event (Baptista et al., 2011), the predicted wave heights are compatible, with no flooding.

The proposed source B generates $0.9 \mathrm{~m}$ for the first wave height but a maximum wave height of $2.2 \mathrm{~m}$. The maximum wave height occurs at 15:00 UTC and the estimated tide is approximately $2.1 \mathrm{~m}$ above HZ. Adding 2.2 to 2.1 we reach spring tide condition of $4.3 \mathrm{~m}$.

Given the considerations above the tide, the analysis favours solution $\mathrm{A}$.

The tidal range in Barbados is about $1 \mathrm{~m}$. This small range might favour the observability of small first waves at tsunami arrival. For source A, the first wave in Barbados is about $0.1 \mathrm{~m}$, which raises the question of whether people might have noticed the advance of the sea. Close to 09:00, $2 \mathrm{~h}$ after tsunami arrival, the positive peak in the VTG is higher than $0.2 \mathrm{~m}$, which results in $0.4 \mathrm{~m}$ when estimating the wave height when applying Green's law for $5 \mathrm{~m}$ depth close to the shore. The coeval sources report similar wave height values.

Also, for source B, the wave height is smaller than $0.1 \mathrm{~m}$ at the VTG at the time of tsunami arrival. About $45 \mathrm{~min}$ later the waves are large than $0.2 \mathrm{~m}$. The maximum peak occurs ca. $2 \mathrm{~h}$ after tsunami arrival at 09:00. Because of the small amplitude of the tide in Barbados, this location does not contribute to selection from the two candidate sources.

The summary (Annual Register, 1761) states that the waves seemed to abate but at 10:00 they started again with a higher intensity and lasted until the next morning - this observation of greater amplitudes some hours after tsunami arrival fits for both sources. However, the timings of increasing wave heights do not match.

In Cadiz, both sources produce the observed withdrawal. Sources A and B predict a drawdown of 0.6 and $0.4 \mathrm{~m}$ respectively. High tide in Cadiz is about $1 \mathrm{~h}$ earlier than in Lisbon. Once the tide is in dropping conditions at the time of the tsunami arrival, a larger drawdown is more likely to be observed.

Considering the points discussed above, we conclude our preferred solution is A-MS. The following facts justify our choice:

- The candidate source in hypothesis A-MS is compatible with the geodynamic setting predicted by the NUVEL 1A model (DeMets et al., 1999). NE-SW compressive structures with comparable fault plane parameters have been identified close to the Coral Patch seamount (Figs. 1 and 3). The proposed structure is possibly propagating and reactivating the NE-SW striking oceanic rifting fabric towards the epicentre suggested by Baptista et al. (2006). Nevertheless, we must stress that Martínez-Loriente et al. (2013) do not suggest an extension of the seismogenic structure at the CPF, although no detailed multi-channel seismic survey has been carried out to the west of the CPF in the proposed source area.

- The wave heights produced by the numerical models are in better agreement with proposed source A-MS.

- Wave heights greater than $14 \mathrm{~m}$ produced by hypothesis $B$ would result in a catastrophic scenario, which is rather unlikely and not observed nor reported. Also, the $4.2 \mathrm{~m}$ wave height produced by hypothesis B in the Azores would have caused inundation, which has not been reported.

- Although both solutions follow our considerations for Lisbon, the wave heights generated by source A-MS seem to be more comparable to the observed fluctuation of $2.4 \mathrm{~m}$ than the wave heights produced by source B.

- The larger drawdown in Cadiz favours solution A-MS. 
The reassessment of the reports of Barbados and Cadiz support the choice selected here. While the tsunami travel time for Barbados supports the source location, the fact that there were no inundation reports in Cadiz supports the magnitude and rupture mechanism proposed here.

\section{Conclusion}

- The source proposed here for the 1761 event is compatible with the tsunami observation data set, the macroseismic intensity data (Baptista et al., 2006) and with the geodynamic context of the area predicted by the kinematic plate model NUVEL 1-A.

- The source proposed here is located in the SWIM, an area of widespread compressive structures (Hayward et al., 1999), corresponding to a fault that extends from the western segment of the CPF towards the epicentre proposed by Baptista et al. (2006).

The investigation of each historical event in the area contributes to a better understanding of the structure of this diffuse plate boundary and ultimately leads to a better evaluation of the seismic and tsunami hazard. This study, together with the study by Baptista et al. (2006), underlines the need to include the 1761 event in all seismic and tsunami hazard assessments in the northeastern Atlantic basin.

Data availability. The DEM for Lisbon and Cadiz can be obtained from the authors. The NSWING code is available at https://github. com/joa-quim/NSWING (Miranda and Luis, 2019) and the corresponding benchmarks can be obtained from the authors.

Author contributions. MW is the leading researcher of this study. He ran most of the models and led the writing process. MAB and JMM validated the analysis of the numerical results and contributed to writing the manuscript.

Competing interests. The authors declare that they have no conflict of interest.

Acknowledgements. This work is funded by FCT (Instituto Dom Luiz; FCT PhD grant ref. PD/BD/135070/2017). The authors wish to thank the editor Ira Didenkulova and the reviewers Uri S. ten Brink, Ceren Özer Sözdinler, Sara Martínez-Loriente and one anonymous referee for their constructive comments and suggestions that greatly helped to improve this manuscript. Finally, the authors wish to thank Pedro Terrinha for his valuable advice and interesting discussions on the geological context of the area and Paul-Louis Blanc for the translation of the report in Journal Historique (1773), and Joaquim Luis for the discussion on the numerical model.
Edited by: Ira Didenkulova

Reviewed by: Uri S. ten Brink, Ceren Ozer Sozdinler,

Sara Martínez-Loriente, and one anonymous referee

\section{References}

Annual Register: available at: available at: https://babel.hathitrust. org/cgi/pt?id=uva.x001119514; view=1up;seq=104 (last access: 31 January 2019), Volume 4, 92-95, 1761.

Argus, D. F., Gordon, R. G., DeMets, C., and Stein, S.: Closure of the Africa-Eurasia-North America plate motion circuit and tectonics of the Gloria fault, J. Geophys. Res.-Sol. Ea., 94, 55855602, https://doi.org/10.1029/JB094iB05p05585, 1989.

Baptista, M. A., Miranda, P. M. A., Miranda, J. M., and Victor, L. M.: Constrains on the source of the 1755 Lisbon tsunami inferred from numerical modelling of historical data on the source of the 1755 Lisbon tsunami, J. Geodyn., 25, 159-174, https://doi.org/10.1016/S0264-3707(97)00020-3, 1998a.

Baptista, M. A., Heitor, S., Miranda, J. M., Miranda, P., and Victor, L. M.: The 1755 Lisbon tsunami; evaluation of the tsunami parameters, J. Geodyn., 25, 143-157, 1998b.

Baptista, M. A., Miranda, J. M., Chierici, F., and Zitellini, N.: New study of the 1755 earthquake source based on multichannel seismic survey data and tsunami modeling, Nat. Hazards Earth Syst. Sci., 3, 333-340, https://doi.org/10.5194/nhess3-333-2003, 2003.

Baptista, M. A., Miranda, J. M., and Luis, J. F.: In search of the 31 March 1761 earthquake and tsunami source, B. Seismol. Soc. Am., 96, 713-7211, https://doi.org/10.1785/0120050111, 2006.

Baptista, M. A., Miranda, J. M., Lopes, F. C., and Luis, J. F.: The source of the 1722 Algarve earthquake: evidence from MCS and Tsunami data, J. Seismol., 11, 371-380, https://doi.org/10.1007/s10950-007-9058-y, 2007.

Baptista, M. A. and Miranda, J. M.: Revision of the Portuguese catalog of tsunamis, Nat. Hazards Earth Syst. Sci., 9, 25-42, https://doi.org/10.5194/nhess-9-25-2009, 2009.

Baptista, M. A., Miranda, J. M., Batlló, J., Lisboa, F., Luis, J., and Maciá, R.: New study on the 1941 Gloria Fault earthquake and tsunami, Nat. Hazards Earth Syst. Sci., 16, 1967-1977, https://doi.org/10.5194/nhess-16-1967-2016, 2016.

Baptista, M. A., Miranda, J. M., Matias, L., and Omira, R.: Synthetic tsunami waveform catalogs with kinematic constraints, Nat. Hazards Earth Syst. Sci., 17, 1253-1265, https://doi.org/10.5194/nhess-17-1253-2017, 2017.

Barkan, R., Uri, S., and Lin, J.: Far field tsunami simulations of the 1755 Lisbon earthquake: Implications for tsunami hazard to the US East Coast and the Caribbean, Mar. Geol., 264, 109-122, https://doi.org/10.1016/j.margeo.2008.10.010, 2009.

Bartolome, R., Gràcia, E., Stich, D., Martínez-Loriente, S., Klaeschen, D., de Lis Mancilla, F., Lo Iacono, C., Dañobeitia, J. J., and Zitellini, N.: Evidence for active strike-slip faulting along the Eurasia-Africa convergence zone: Implications for seismic hazard in the southwest Iberian margin, Geology, 40, 495-498, 2012.

Bellin, J. N.: Carte hydrographique de La Baye De Cadix, Versailles, 1762.

Blaser, L., Krüger, F., Ohrnberger, M., and Scherbaum, F.: Scaling relations of earthquake source parameter estimates with special 
focus on subduction environment, B. Seismol. Soc. Am., 100, 2914-2926, https://doi.org/10.1785/0120100111, 2010.

Borlase, W.: Some Account of the extraordinary Agitation of the Waters in Mount's-bay, and other Places, on the 31st of March 1761: In a Letter for the Reverend C. Lyttelton, Philos. T. Roy. Soc., 52, 418-431, 1762.

Custódio, S., Dias, N. A., Carrilho, F., Góngora, E., Rio, I., Marreiros, C., Morais, I., Alves, P., and Matias, L.: Earthquakes in western Iberia: Improving the understanding of lithospheric deformation in a slowly deforming region, Geophys. J. Int., 203, 127-145, https://doi.org/10.1093/gji/ggv285, 2015.

Davies, G., Griffin, J., Løvholt, F., Glimsdal, S., Harbitz, C., Thio, H. K., Lorito, S., Basili, R., Selva, J., Geist, E., and Baptista, M. A.: A global probabilistic tsunami hazard assessment from earthquake sources. Geological Society, London, Special Publications, 456, 219-244, 2018.

DeMets, C., Gordon, R. G., Argus, D. F., and Stein, S.: Current plate motions, Geophys. J. Int., 101, 425-478, 1990.

DeMets, C., Gordon, R. G., Argus, D. F., and Stein, S.: Effect of recent revisions to the geomagnetic reversal time scale on estimates of current plate motions, Geophys. Res. Lett., 21, 21912194, https://doi.org/10.1029/94GL02118, 1994.

DeMets, C. and Dixon, T. H.: New kinematic models for Pacific-North America motion from $3 \mathrm{Ma}$ to present, I: Evidence for steady motion and biases in the NUVEL-1A model, Geophys. Res. Lett., 26, 1921-1924, https://doi.org/10.1029/1999GL900405, 1999.

Duarte, J. C., Rosas, F. M., Terrinha, P., Schellart, W. P., Boutelier, D., Gutscher, M. A., and Ribeiro, A.: Are subduction zones invading the Atlantic? Evidence from the southwest Iberia margin, Geology, 41, 839-842, https://doi.org/10.1130/G34100.1, 2013.

Fearns, J.: Letter to The London Chronicle, No. 731, p. 214, available at: https://newspaperarchive.com/uk/middlesex/london/ london-chronicle/ (last access: 31 January 2019), 1761.

Fernandes, R. M. S., Bastos, L., Miranda, J. M., Lourenço, N., Ambrosius, B. A. C., Noomen, R., and Simons, W.: Defining the plate boundaries in the Azores region, J. Volcanol. Geoth. Res., 156, 1-9, https://doi.org/10.1016/j.jvolgeores.2006.03.019, 2006.

Fernandes, R. M. S., Miranda, J. M., Meijninger, B. M. L., Bos, M. S., Noomen, R., Bastos, L., Ambrosius, B. A. C., and Riva, R. E. M.: Surface velocity field of the Ibero-Maghrebian segment of the Eurasia-Nubia plate boundary, Geophys. J. Int., 169, 315324, 2007.

GEBCO: The General Bathymetric Chart of the Oceans, GEBCO_2014 grid, version 20150318, available at: http://www. gebco.net (last access: 1 February 2018), 2014.

Geissler, W. H., Matias, L., Stich, D., Carrilho, F., Jokat, W., Monna, S., IbenBrahim, A. Mancilla, F., Gutscher, M.-A., Sallarès, V., and Zitellini, N.: Focal mechanisms for sub-crustal earthquakes in the Gulf of Cadiz from a dense OBS deployment, Geophys. Res. Lett., 37, L18309, https://doi.org/10.1029/2010GL044289, 2010.

Gràcia, E., Dañobeitia, J. J., Vergés, J., and PARSIFAL Team: Mapping active faults offshore Portugal $\left(36^{\circ} \mathrm{N}-38^{\circ} \mathrm{N}\right)$ : Implications for seismic hazard assessment along the southwest Iberian margin, Geology, 31, 83-86, 2003.
Green, G.: On the motion of waves in a variable canal of small depth and width, Transactions of the Cambridge Philosophical Society, 6, 457-462, 1838.

Gutenberg, B. and Richter, C. F.: Seismicity of the Earth and associated phenomena, Princeton University Press, Princeton, New Jersey, 1949.

Gutscher, M. A., Malod, J., Rehault, J. P., Contrucci, I., Klingelhoefer, F., Mendes-Victor, L., and Spakman, W.: Evidence for active subduction beneath Gibraltar, Geology, 30, 1071-1074, https://doi.org/10.1130/00917613(2002)030<1071:EFASBG>2.0.CO;2, 2002.

Gutscher, M. A., Baptista, M. A., and Miranda, J. M.: The Gibraltar Arc seismogenic zone (part 2): constraints on a shallow east dipping fault plane source for the 1755 Lisbon earthquake provided by tsunami modeling and seismic intensity, Tectonophysics, 426 , 153-166, https://doi.org/10.1016/j.tecto.2006.02.025, 2006.

Gutscher, M. A., Dominguez, S., Westbrook, G. K., Le Roy, P., Rosas, F., Duarte, J. C., Terrinha, P., Miranda, J. M., Graindorge, D., Sallares, V., and Bartolome, R.: The Gibraltar subduction: A decade of new geophysical data, Tectonophysics, 574, 72-91, https://doi.org/10.1016/j.tecto.2012.08.038, 2012.

Hayward, A., Watts, A. B., Westbrook G. K., and Collier J. S.: A seismic reflection and GLORIA study of compressional deformation in the Gorringe Bank region, Eastern North Atlantic, Geophys. J. Int., 138, 831-850, https://doi.org/10.1046/j.1365246x.1999.00912.x, 1999.

Heberden, T.: An Account of the Earthquake felt in the Island of Madeira, 31 March 1761, communicated by Heberden, W., Philos. T. Roy. Soc., 52, p.155, 1761.

Hébert, H., and Schindelé, F.: Tsunami impact computed from offshore modeling and coastal amplification laws: insights from the 2004 Indian Ocean Tsunami, Pure Appl. Geophys., 172, 33853407, 2015.

Instituto Geográfico Nacional (IGN): available at: http://www.ign. es/web/ign/portal/sis-catalogo-terremotos/, last access: 1 February 2018.

Jiménez-Munt, I., Fernàndez, M., Vergés, J., Afonso, J. C., GarciaCastellanos, D., and Fullea, J.: Lithospheric structure of the Gorringe Bank: Insights into its origin and tectonic evolution, Tectonics, 29, TC5019, https://doi.org/10.1029/2009TC002458, 2010.

Johnston, A. C.: Seismic moment assessment of earthquakes in stable continental regions - III, New Madrid 1811-1812, Charleston 1886 and Lisbon 1755, Geophys. J. Int., 126, 314344, https://doi.org/10.1111/j.1365-246X.1996.tb05294.x, 1996.

Journal Historique: Suite de La Clef ou Journal Historique sur Les Matieres du Tems, contenant quelques nouvelles de Litterature, et autres Remarques curieuses, Juin 1773, Premiere Partie, Tome CXIII, Paris, 462-464, 1773 (in French).

Kaabouben, F., Brahim, A. I., Toto, E., Baptista, M. A., Miranda, J. M., Soares, P., and Luis, J. F.: On the focal mechanism of the 26.05.1975 North Atlantic event contribution from tsunami modeling, J. Seismol., 12, 575-583, 2008.

Kaabouben, F., Baptista, M. A., Iben Brahim, A., El Mouraouah, A., and Toto, A.: On the moroccan tsunami catalogue, Nat. Hazards Earth Syst. Sci., 9, 1227-1236, https://doi.org/10.5194/nhess-91227-2009, 2009.

Laughton, A. S. and Whitmarsh, R. B.: The Azores-Gibraltar plate boundary, in: Geodynamics of Iceland and the North 
Atlantic area, edited by: Kristjansson, L., NATO Advanced Study Institute, Reykjavik, Springer, the Netherlands, 63-81, https://doi.org/10.1007/978-94-010-2271-2_5, 1974.

Liu, P. L. F., Cho, Y. S., Briggs, M. J., Kanoglu, U., and Synolakis, C. E.: Runup of solitary waves on a circular island, J. Fluid Mech., 302, 259285, https://doi.org/10.1017/S0022112095004095, 1995.

Liu, P. L., Woo, S. B., and Cho, Y. S.: Computer programs for tsunami propagation and inundation, Cornell University, available at: http://tsunamiportal.nacse.org/documentation/ COMCOT_tech.pdf (last access: 1 February 2018), 1998.

Luis, J. F.: Mirone: A multi-purpose tool for exploring grid data, Comput. Geosci., 33, 31-41, https://doi.org/10.1016/j.cageo.2006.05.005, 2007.

Lynnes, C. S. and Ruff, L. J.: Source process and tectonic implications of the great 1975 North Atlantic earthquake, Geophys. J. Int., 82, 497-510, 1985.

Manighetti, I., Campillo, M., Bouley, S., and Cotton, F.: Earthquake scaling, fault segmentation, and structural maturity, Earth Planet. Sc. Lett., 253, 429-438, https://doi.org/10.1016/j.epsl.2006.11.004, 2007.

Mansinha, L. and Smylie, D. E.: The displacement fields of inclined faults, B. Seismol. Soc. Am., 61, 1433-1440, 1971.

Martínez-Loriente, S., Gràcia, E., Bartolome, R., Sallarès, V., Connors, C., Perea, H., Lo Iacono, C., Klaeschen, D., Terrinha P., Dañobeitia J. J., and Zitellini, N.: Active deformation in old oceanic lithosphere and significance for earthquake hazard: Seismic imaging of the Coral Patch Ridge area and neighboring abyssal plains (SW Iberian Margin), Geochem. Geophy. Geosy., 14, 2206-2231, https://doi.org/10.1002/ggge.20173, 2013.

Martínez-Loriente, S., Sallarès, V., Gràcia, E., Bartolome, R., Dañobeitia, J. J., and Zitellini, N.: Seismic and gravity constraints on the nature of the basement in the Africa-Eurasia plate boundary: New insights for the geodynamic evolution of the SW Iberian Margin, J. Geophys. Res., 119, 127-149, https://doi.org/10.1002/2013JB010476, 2014.

Martínez-Loriente, S., Gràcia, E., Bartolome, R., Perea, H., Klaeschen, D., Dañobeitia, J. J., Zitellini, N., Wynn, R. B., and Masson, D. G.: Morphostructure, tectono-sedimentary evolution and seismic potential of the Horseshoe Fault, SW Iberian Margin, Basin Res., 30, 382-400, https://doi.org/10.1111/bre.12225, 2018.

Mason, A.: Letter to the Reverend Thomas Birch, D. D. Secretary to the Royal Society, relating to an extraordinary agitation of the Sea there, 31st of March 1761, Philos. T. Roy. Soc., 52, 477-478, 1761.

Matias, L. M., Cunha, T., Annunziato, A., Baptista, M. A., and Carrilho, F.: Tsunamigenic earthquakes in the Gulf of Cadiz: fault model and recurrence, Nat. Hazards Earth Syst. Sci., 13, 1-13, https://doi.org/10.5194/nhess-13-1-2013, 2013.

Mezcua, J. and Solares, J. M. M.: Sismicidad del área Iberomogrebí, I.G.N., no. 203, Madrid, 301 pp., available at: http://www.ign.es/web/resources/sismologia/publicaciones/

/SismicidaddelAreaIberoMogrebi.pdf (last access: 15 January 2019), 1983.

Miranda, J. M. and Luis, J.: NSWING (Non-linear Shallow Water model With Nested Grids), Instituto Dom Luiz, available at: https://github.com/joa-quim/NSWING, last access: 29 January 2019.
Miranda, J. M., Baptista, M. A., and Omira, R.: On the use of Green's summation for tsunami waveform estimation: a case study, Geophys. J. Int., 199, 459-464, https://doi.org/10.1093/gji/ggu266, 2014.

Molloy, M.: XXVII. Another account of the same earth-quake: In a letter from Mr. Molloy, dated there 3 April 1761, to Keane Fitzgerald, Esq; F. R. S, Philos. T. Roy. Soc., 52, 142-143, https://doi.org/10.1098/rstl.1761.0028, 1761.

Moreira, V. S.: Sismicidade histórica de Portugal Continental, Rev. Inst. Nac. Met. e Geofísica, Março, March 1984, 3-79, 1984.

Nocquet, J. M. and Calais, E.: Geodetic measurements of crustal deformation in the Western Mediterranean and Europe, Pure Appl. Geophys., 161, 661-681, 2004.

Oliveira, C. S.: A sismicidade Histórica em Portugal Continental e a Revisão do Catálogo sísmico Nacional, Laboratório Nacional de Engenharia Civil, Proc. 36/1177638, 235, Lisboa, Portugal, 1986.

Omira, R., Baptista, M. A., and Matias, L.: Probabilistic tsunami hazard in the Northeast Atlantic from near-and farfield tectonic sources, Pure Appl. Geophys., 172, 901-920, https://doi.org/10.1007/s00024-014-0949-x, 2015.

Ribeiro, A., Mendes-Victor, L., Cabral, J. M. L. C., Matias, L., and Terrinha, P.: The 1755 Lisbon earthquake and the beginning of closure of the Atlantic, Eur. Rev., 14, 193-205, https://doi.org/10.1017/S1062798706000196, 2006.

Rocque, J.: A Plan of the City of Cadiz and the environs with the Harbour, Bay and Soundings at Low Water also a Particular Plan of the Town and Fortifications from the Collection of Capt. Clark and Improved by the late John Rocque, Topographer to his Majesty, Bibliothèque nationale de France, département Cartes et plans, CPL GE DD-2987, 1762.

Rosas, F. M., Duarte, J. C., Terrinha, P., Valadares, V., and Matias, L.: Morphotectonic characterization of major bathymetric lineaments in Gulf of Cadiz (Africa-Iberia plate boundary): insights from analogue modelling experiments, Mar. Geol., 261, 33-47, https://doi.org/10.1016/j.margeo.2008.08.002, 2009.

Sallarès, V., Martínez-Loriente, S., Prada, M., Gràcia, E., Ranero, C. R., Gutscher, M. A., Bartolome, R., Gailler, A., Dañobeitia, J. J., and Zitellini, N.: Seismic evidence of exhumed mantle rock basement at the Gorringe Bank and the adjacent Horseshoe and Tagus abyssal plains (SW Iberia), Earth Planet. Sc. Lett., 365, 120-131, https://doi.org/10.1016/j.eps1.2013.01.021, 2013.

Silva, S., Terrinha, P., Matias, L., Duarte, J. C., Roque, C., Ranero, C. R., Geissler, W. H., and Zitellini, N.: Micro-seismicity in the Gulf of Cadiz: Is there a link between micro-seismicity, high magnitude earthquakes and active faults?, Tectonophysics, 717, 226-241, 2017.

Solares, J. M. and Lopez-Arroyo, A.: The great historical 1755 earthquake: Effects and damage in Spain, J. Seismol., 8, 275294, https://doi.org/10.1023/B:JOSE.0000021365.94606.03, 2004.

Synolakis, C. E., Bernard, E. N., Titov, V. V., Kânoğlu, U., and Gonzalez, F. I.: Validation and verification of tsunami numerical models, In Tsunami Science Four Years after the 2004 Indian Ocean Tsunami 2197-2228, Birkhäuser Basel, https://doi.org/10.1007/s00024-004-0427-y, 2008.

Terrinha, P., Pinheiro, L. M., Henriet, J. P., Matias, L., Ivanov, M. K., Monteiro, J. H., Akhmetzhanov, A., Volkonskaya, A., Cunha, T., Shaskin, P., and Rovere, M.: Tsunamigenic-seismogenic 
structures, neotectonics, sedimentary processes and slope instability on the southwest Portuguese Margin, Mar. Geol., 195, 5573, 2003.

Terrinha, P., Matias, L., Vicente, J., Duarte, J., Luís, J., Pinheiro, L., Lourenço, N., Diez, S. Rosas, F., Magalhães, V., Valadares, V., Zitellini, N., Roque, C., Mendes Víctor, L., and MATESPRO Team.: Morphotectonics and strain partitioning at the Iberia-Africa plate boundary from multibeam and seismic reflection data, Mar. Geol., 267, 156-174, https://doi.org/10.1016/j.margeo.2009.09.012, 2009.

Torelli, L., Sartori, R., and Zitellini, N.: The giant chaotic body in the Atlantic Ocean off Gibraltar: new results from a deep seismic reflection survey, Mar. Petrol. Geol., 14, 125-134, https://doi.org/10.1016/S0264-8172(96)00060-8, 1997.

UC-IGN: Tsunami inundation maps along the south west Spanish coast, deliverable d7.1 of the 6th European framework programme project TRANSFER, available at: https://cordis.europa. eu/project/rcn/81399/factsheet/en (last access: 1 August 2018), 2009.

Unknown: An Account of the Earthquake at Lisbon, 31 March 1761: In a Letter from thence, dated 2 April 1761, to Joseph Salvador, Esq. F.R.S. Philos. Trans. Letter XXVI, 141-142, 1761.

USNO (United States Naval Observatory): available at: http://aa. usno.navy.mil/data/docs/MoonPhase.php (last access: 1 February 2018), 2017.

Wells, D. L. and Coppersmith, K. J.: New empirical relationships among magnitude, rupture length, rupture width, rupture area, and surface displacement, B. Seismol. Soc. Am., 84, 974-1002, 1994.

Wronna, M., Omira, R., and Baptista, M. A.: Deterministic approach for multiple-source tsunami hazard assessment for Sines, Portugal, Nat. Hazards Earth Syst. Sci., 15, 2557-2568, https://doi.org/10.5194/nhess-15-2557-2015, 2015.
Wronna, M., Baptista, M. A., and Götz, J.: On the construction and use of a Paleo-DEM to reproduce tsunami inundation in a historical urban environment-the case of the 1755 Lisbon tsunami in Cascais, Geomat. Nat. Haz. Risk, 8, 841-862, https://doi.org/10.1080/19475705.2016.1271832, 2017.

Zitellini, N., Chierici, F., Sartori, R., and Torelli, L.: The tectonic source of the 1755 Lisbon earthquake and tsunami, Ann. Geophys.-Italy, 42, 49-55, https://doi.org/10.4401/ag3699, 1999.

Zitellini, N., Mendes, L. A., Cordoba, D., Dañobeitia, J. J., Nicolich, R., Pellis, G., Ribeiro, A., Sartori, R., Torelli, L., Bartolome, R., Bortoluzzi, G., Calafato, A., Carrilho, F., Casoni, L., Chierici, F., Corela, C., Correggiari, A., Delia Vedova, B., Gracia, E., Jornet, P., Landuzzi, M., Ligi, M., Magagnoli, A., Marozzi, G., Matias, L., Penitenti, D., Rodriguez, P., Rovere, M., Terrinha, P., Vigliotti, L., and Zahinos Ruiz, A.: Source of 1755 Lisbon earthquake and tsunami investigated, Eos, Transactions American Geophysical Union, 82, 285-291, https://doi.org/10.1029/EO082i026p00285-01, 2001.

Zitellini, N., Rovere, M., Terrinha, P., Chierici, F., Matias, L., and BIGSETS Team: Neogene through Quaternary tectonic reactivation of SW Iberian Passive Margin, Pure Appl. Geophys., 161, 565-587, 2004.

Zitellini, N., Gràcia, E., Matias, L., Terrinha, P., Abreu, M. A., DeAlteriis, G., Henriet, J. P., Dañobeitia, J. J., Masson, D. G., Mulder, T., Ramella, R., Somoza, L., and Diez, S.: The quest for the Africa-Eurasia plate boundary west of the Strait of Gibraltar, Earth Planet. Sc. Lett., 280, 13-50, https://doi.org/10.1016/j.eps1.2008.12.005, 2009. 